Portland State University

PDXScholar

Fall 11-28-2017

\title{
The Use of Evidentials in Hearsay Contexts in Japanese and English
}

Tomomi Matsumura

Portland State University

Follow this and additional works at: https://pdxscholar.library.pdx.edu/open_access_etds

Part of the Japanese Studies Commons, and the Linguistics Commons Let us know how access to this document benefits you.

Recommended Citation

Matsumura, Tomomi, "The Use of Evidentials in Hearsay Contexts in Japanese and English" (2017). Dissertations and Theses. Paper 4153.

https://doi.org/10.15760/etd.6041

This Thesis is brought to you for free and open access. It has been accepted for inclusion in Dissertations and Theses by an authorized administrator of PDXScholar. Please contact us if we can make this document more accessible: pdxscholar@pdx.edu. 
The Use of Evidentials in Hearsay Contexts in Japanese and English

by

Tomomi Matsumura

A thesis submitted in partial fulfillment of the requirements for the degree of

\author{
Master of Arts \\ in \\ Japanese
}

Thesis Committee:

Suwako Watanabe, Chair

Jon Holt

Karen Curtin

Portland State University

2017 
(C) 2017 Tomomi Matsumura 


\begin{abstract}
Evidentials are one of the language codes that convey the speaker's beliefs in terms of the degree of reliability of information and how the speaker obtained information (Chafe, 1986; Ishida, 2006; McCready and Ogata, 2007). Evidentials play an important role in communication since they also function to show the speaker's attitude toward the interlocutors by making a sentence softer (Trent 1998). In his theory of territory of information, Kamio $(1990,1997,2002)$ proposed that pragmatic rules of evidentials are different in Japanese than in English. Ishida (2006) studied these differences and argued that learners of Japanese (JF learners) face difficulties when conveying information with evidentials in Japanese.

This study aimed to see how learners of Japanese as a foreign language (hereafter JF learners) use evidentials differently from Japanese native speakers by replicating Ishida's (2006) study. Discourse data, consisting of utterances produced by Japanese L1 speakers (J-speakers) in Japanese and JF learners in Japanese and English, was produced based on twelve situations where participants were instructed to convey hearsay information verbally to the specific third party. Collected productions were compared to see differences in the frequencies of evidentials, in general, and in terms of the source of information, the timing of conveyance, and the addressees. The study showed that JF learners use evidentials less frequently both in Japanese and English than J-speakers. This less frequent use of evidentials by JF learners in both languages indicates a transfer effect from English to Japanese. Additionally, a close look at each evidential use revealed other factors that might impact the speaker's choice of evidentials. This
\end{abstract}


study revealed that JF learners tend to prefer to use evidentials such as soo da and to itta, while they tend to avoid using lexical evidentials such as rashii, mitai $d a$, and yoo da which require more practice. These findings have implications for future research and for classroom pedagogical approaches to the use of evidentials. 


\section{ACKOWLEDGEMENTS}

I would like to express my sincerest gratitude to my advisor, Dr. Suwako Watanabe, without whose understanding, patience and encouragement I could not have completed this thesis. Since the time I had the pleasure of being her student in a pedagogy class in 2016, her dedication to the field and support of all her students have inspired me and encouraged my pursuit of a graduate degree in Japanese. I would also like to thank the other members of my committee, Dr. Jon Holt and Dr. Karen Curtin, for helping me develop my current fascination with Japanese literature and linguistics. In addition, I would like to acknowledge Dr. Larry Kominz for his support of my teaching and studies. I would also like to express my special thanks to Dr. Linnea Spitzer, who offered me insights and generous assistance with my thesis. I am indebted to my numerous friends, students, and colleagues who shared their invaluable thoughts and supported my teaching and study. There are so many, but an incomplete list would include Benjamin Burton, Nobuko Horikawa, Natsuko Llewellyn, Nao Okumura, Narumi Iwataki, Mina Asai, Paolo Menuez and Kumiko Takizawa. Thank you very much. 


\section{TABLE OF CONTENTS}

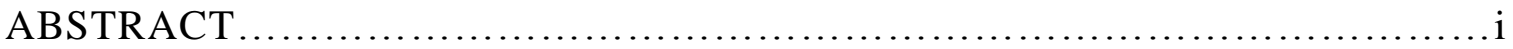

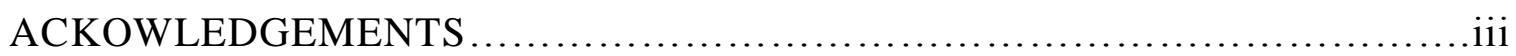

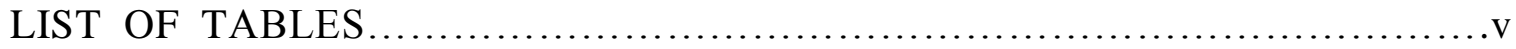

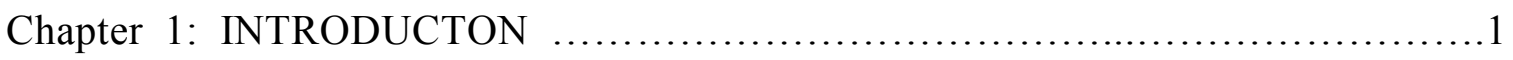

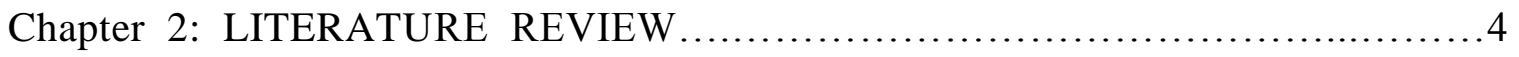

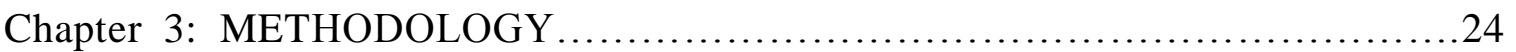

Chapter 4: RESULTS AND DISCUSSION................................. 37

Chapter 5: CONCLUSION...............................................69

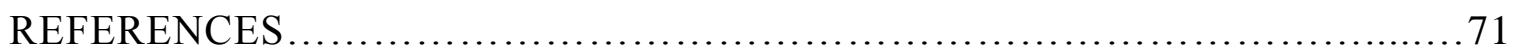

\section{APPENDICES}

A. INFORMED CONSENT FORM......................................... 76

B. E-MAIL TO NATIVE JAPANESE SPEAKERS.............................78

C. E-MAIL TO NATIVE JAPANESE SPEAKERS ..................................79

D. D2L ANNOUNCEMENT TO LEARNERS ................................ 81

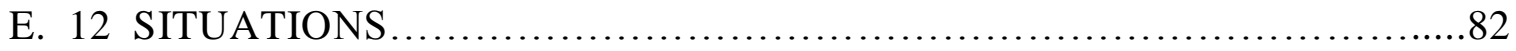

F. FOLLOW-UP QUESTIONS .......................................... 88 


\section{LIST OF TABLES}

TABLE 1

Ishida's Groups of Japanese Evidentials.

TABLE 2

The Groups of Evidentials.

TABLE 3

The Frequency of the Use of Evidentials.

TABLE 4

Total Frequency of the Use of Evidentials

Depending on the Source of Information without Situation $12 \ldots \ldots \ldots \ldots \ldots \ldots \ldots . \ldots 1$

TABLE 5

Total Frequency of the Use of Evidentials

Depending on Timing of Conveyance without Situation $12 \ldots \ldots \ldots \ldots \ldots \ldots \ldots \ldots . \ldots . \ldots . \ldots . \ldots 4$

TABLE 6

Total Frequency of the Use of Evidentials

Depending Addressee without Situation 1..................................47

TABLE 7

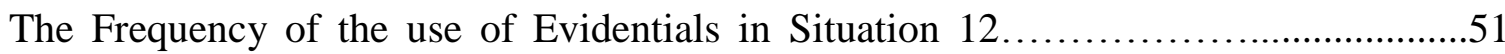

TABLE 8

Frequency of the use of the different groups of Evidentials.

TABLE 9

Frequency of the use of the Different Groups of Evidentials

Depending on the Addressee. 


\section{CHAPTER 1:}

\section{INTRODUCTION}

In second language acquisition (SLA), there is much discussion regarding language differences in terms of linguistic and sociolinguistic pragmatic rules from various approaches since these rules differ from one language to another (Ellis, 1997). Due to these different rules, language learners often make mistakes. Pragmatic rules of evidentials are different in English and Japanese, and so English L1 speakers who learn Japanese frequently misuse these evidentials when producing sentences in Japanese (Ishida, 2006; Kamio 1995; Mushin, 1998; Trent, 1998).

Evidentials are a type of language device that can express the speaker's awareness in language (Chafe, 1986). Evidentials are phrases such as "I hear" or "it looks like" in English and to kiita or mitai da in Japanese. According to Chafe, evidentials provide "a repertoire of devices for conveying these various attitudes toward knowledge ... [regarding] the source and reliability" (vii). McCready and Ogata (2007) define evidentials as a language device that "serve[s] to indicate where a given piece of knowledge came from and the degree of reliability the speaker assigns to it (p. 149)." Evidentials serve dual purposes. First, they convey the speaker's degree of certainty concerning the truth based on how they obtained information (Chafe, 1986; Ishida, 2006; McCready and Ogata, 2007); and second, they can be used to show the speaker's polite attitude by softening sentences (Trent 1998). So evidentials are devices that indicate where the piece of information came from, whether tactile, visual, auditory, internal sensory, unknown, judgmental, or reported (McCready and Ogata, 2007), and how reliable this information is for the speaker. Since evidentials show the speaker's 
knowledge regarding the source and reliability, they are often used when conveying hearsay information.

The use of evidentials may differ from language to language, and so learners of foreign languages face difficulty in mastery. Without fully mastering the differences in pragmatic knowledge between their first language (L1) and target language (TL), learners might apply their L1 knowledge to their TL (Kamada 1990). Ishida (2006) conducted a quantitative study regarding evidentials about how English L1 learners of Japanese use evidentials both in Japanese and in English and compared them with Japanese L1 speakers' utterances. His data showed that learners of Japanese use evidentials less frequently both in English and Japanese than Japanese L1 speakers. He concluded that there was a transfer effect, meaning they transferred their English pragmatic knowledge into Japanese without noticing. Due to the learners' lack of pragmatic rules regarding Japanese evidentials, learners of Japanese may exhibit less frequent use of evidentials than they did in their L1 (Ishida, 2006).

Producing sentences that contain inappropriate evidentials may cause misunderstandings or create unintended impressions, and as a result, this may affect the relationship between the speaker and the hearer. For instance, Trent (1998) pointed out that cultural preferences in Japanese and American cultures are different. According to Trent, sentences without evidentials, which may occur often in English, sound too direct and assertive to Japanese L1 speakers. These sentences may make Japanese speakers uncomfortable. In order to avoid these problems, learners of Japanese need to be aware of pragmatic rules and master their use. 
This study addresses the question of whether learners of Japanese and native Japanese speakers convey hearsay information differently by replicating Ishida's study (2006) on the use of evidentials. In addition to replicating Ishida's study, this study aims to identify which evidentials are difficult to master by analyzing each type of evidential closely and to suggest how instructors can deal with them. Although Ishida's study found that learners of Japanese tend to omit evidentials because of the transfer effect, he neither conducted a close analysis on each evidential nor did he provide pedagogical implications. This study will introduce factors that may affect the use of evidentials other than those presented in Ishida's study, such as cultural preferences, and learner's learning environment. The study will help enhance our understanding about Japanese evidentials and improve a pedagogical approach to teaching how to convey hearsay information using evidentials in Japanese. 


\section{CHAPTER 2:}

\section{LITERATURE REVIEW}

In this chapter, I will discuss the differences between Japanese and English use of evidentials. I will first review the essential research regarding evidentials: Ishida's study (2006) regarding JF learner's transfer effect, Kamio’s theory of territory of the information (1995, 1997, 2001), and Kamada's (1990) and Trent's (1998) study regarding the use of evidentials in hearsay contexts. Second, I will present the features and definitions of Japanese evidential types. By comparing context and usage of each evidential, this section gives a through explanation for each evidential, including soo da, rashii, and yoo dalmitai da. Lastly, I will present the research questions of this study.

\section{1. Pragmatic Knowledge and the Transfer Effect}

In the field of second language acquisition (SLA), "linguistic knowledge" and "pragmatic knowledge" are frequently discussed. Understanding pragmatic knowledge is the key to mastering the use of evidentials in the target language (TL). Pragmatic knowledge may differ from one language to another, and many SLA studies report that evidentials in English, German, Spanish, Chinese, and Japanese are different (Ellis, 1997). According to Ellis, linguistic competence refers to "the knowledge of the formal properties of languages, in particular of grammar," while pragmatic competence refers to "the knowledge of the rules for using languages in context". Linguistic competence is knowledge only about grammar, such as plural formations, tense refraction, and prepositions, while pragmatic competence involves a speaker's attempt to use their knowledge in actual acts of communication. 
Transfer of practical differences between languages could cause misunderstandings or worse, in some cases, they can create negative impressions of the speaker. In order to avoid this misuse of evidentials, learners of a target language (TL) should be aware of the differences of pragmatic knowledge in their L1 and TL.

If learners do not internalize the differences in their L1 and TL, they may produce ungrammatical or inappropriate sentences in the TL. Many studies indicate that learners assume they can transfer their linguistic knowledge of L1 into their TL, without knowing that they lack pragmatic knowledge, and their TL productions may be problematic (Ishida, 2006; Kamada, 1990; Trent, 1998). The transfer effect happens when the language learners transfer their L1 pragmatic rules into their TL. This transfer effect can have a positive or negative effect. If pragmatic rules in the TL are different from the speaker's L1, they tend to make mistakes when producing sentences in the TL. Kamada (1990) and Ishida (2006) suggest that learners of Japanese often lack awareness of these differences and tend to transfer their L1 knowledge of linguistic and pragmatic rules to their TL, in this case, Japanese. In the next section, Ishida's study (2006) will be discussed in detail.

\section{2. Ishida's (2006) Study}

Ishida (2006) states that the tendency towards lack of Japanese evidentials in learners' sentences may be attributed to the different pragmatic rules in Japanese and English. He conducted a quantitative study investigating utterances that contain evidentials in Japanese and English. The participants of his study were ten native English speakers who have studied Japanese language more than three years under formal 
instruction and have lived in Japan for more than three months, and ten native Japanese speakers ${ }^{1}$. To study evidentials of learners of Japanese, he first created a set of situations where certain information was conveyed by a person or the media. He read each situation and then asked participants to convey the information based on the situations to another imaginary recipient, either "family," "friend," or "superior." Learners of Japanese produced utterances in both English and Japanese, and native Japanese participants produced utterances only in Japanese. Ishida's study showed that learners of Japanese used fewer evidentials both in English and Japanese than native Japanese speakers and proposed there is a learner's transfer effect from their L1 to their L2.

In his study, Ishida (2006) incorporated into the situations the following three variations that make differences in English and Japanese as proposed by Kamio: timing (immediately, a little later within the same day, or one day, which is after night and the following morning), source of information (family, friends or media), and status of message recipient (friends, family or superiors). I will present Kamio's (2001) theory of territory of information.

\section{3. 1. Kamio's (2001) Theory of Territory of Information}

In his theory of "territory of information," Kamio (2001) compares pragmatic rules in Japanese language and English in terms of evidentials. Kamio uses the notion of territory and explains that the sentence-final form indicates the degree of certainty of the speaker and the speaker's assumption about the hearer's degree of certainty, and whether the information falls into the speaker's territory or the hearer's territory. Kamio suggests

${ }^{1}$ Ishida (2006) did not mention the background of the Japanese L1 speakers in his article. 
that information is located on the spectrum scales of a speaker and a hearer and introduces detailed types of situations that help to decide where information belongs. By analyzing where information falls within and whether it is on the speaker's territory or the hearer's territory, he presents various usage of evidentials including sentence final particles ne and yoo da and mitai da.

For example, suppose that Taro, the exchange student who currently lives in Oregon in the U.S., and Mika, his mother who lives in Japan, are talking on the phone. When Taro talks about Oregon's weather to Mika, he says Oregon wa totemo samui yo "Oregon is really cold." In this case, Taro certainly knows that Oregon is cold through his direct experience. However, when Mika conveys the information heard from Taro to her husband, she may say Oregon wa totemo samui mitai yo "It seems that Oregon is really cold," because she had obtained this information from Taro, rather than a direct experience; thus, the information is not in Mika's territory and, therefore, does not contain a high degree of certainty for Mika.

Kamio (2001) proposes that utterances conveying second-hand information may be different in Japanese and English. According to Kamio, hearsay information is one of the linguistic devices that speakers use to mark a lower degree of certainty. When the speaker obtains the information from external sources rather than internal direct experiences, the information is marked with certain linguistic devices that indicate a lack of certainty. As discussed, the final-sentence form, which may contain evidentials, can mark hearsay information. He proposes three factors that may contribute to these differences. 


\section{3. 2. Degree of Reliability}

Kamio (2001) first points out that, in English, if second-hand information has a high degree of reliability, the speaker likely omits evidentials and uses a direct form. Suppose that Taro and his brother, Akira, are at home and playing a game. Taro receives a phone call from their mother and the mother says "I will be coming back in a few minutes". When Taro conveys the information about the mother to his brother, in English, he can say "she will be coming back in a few minutes", using a direct form. However, in Japanese, even though the information has a high degree of reliability, it is still considered to be second-hand. That is, in Japanese, the speaker may say Okaasan ato suuhun de kaette kuru tte, "it's said she will be coming back in a few minutes", with evidentials.

\section{3. 3. Timing of Conveyance}

Kamio (2001) then proposes that the timing of conveying information in relation to the time of acquiring the information is another factor that is different between Japanese and English. When conveying second-hand information in Japanese, the information is conveyed with evidentials until considerable processing of the information takes place. In other words, in Japanese, a sufficient amount of time to process the second-hand information is required before it can be turned into the speaker's information. Suppose that a father who lives away from home receives a phone call from his wife. The wife tells him that their daughter, Yuki,who had taken an entrance exam, was accepted into a university. According to Kamio, when the father conveys the information about his daughter to his colleague immediately after the phone call in 
Japanese, he will likely say; Yuki ga gookaku shita mitai desu "It seems like Yuki has passed the entrance exam," with evidentials.

However, if he conveys the same information one day after receiving the phone call, he can say Yuki ga gookaku shimasita, "Yuki has passed the entrance exam" without any evidentials. This indicates that if sufficient time has passed after obtaining the information, the process has taken place and the news comes to be considered as the speaker's personal information in Japanese. Due to this process, the speaker is able to convey this information without evidentials. On the other hand, English does not require this time interval; thus, the information can be conveyed in direct form even immediately after receiving the information. There are no pragmatic rules regarding the use of evidentials in relation to timing in English.

\section{3. 4. Politeness Strategy and Addressees}

Kamio (2001) finally suggests that the speaker's notion regarding "politeness" toward an addressee is another factor that affects the speaker's choice of evidentials both in Japanese and English. Kamio proposes that sentences with evidentials make sentences sound softer and give a polite impression in both languages. This politeness strategy affects the conveyance of second-hand information in terms of the choice of evidentials. He proposes that there are cases in which the speaker uses evidentials to show their polite attitude toward the addressee in order to sound humble, even when the speaker has a high degree of reliability and can be conveyed in direct form. In the previous situation, the father can say Yuki ga gookaku shita mitai desu "It seems like Yuki has passed the entrance exam" to his colleague in indirect form with a concern for politeness towards his 
colleague. In contrast, the father may omit evidentials in this situation and say Yuki ga goukaku shimasita to make his utterance more direct and to show closeness.

Kamio (2001) presented pragmatic usage of evidentials that differ in English and Japanese based on the three factors of reliability, timing, and politeness within the theory of territory of information. By explaining situations that English L1 speaker can omit evidentials in English while not in Japanese, he proposed that English L1 speakers use evidentials in hearsay contexts less frequently than J-speakers. In order to examine the three factors proposed by Kamio (2001), Ishida (2006) incorporated them into the twelve hearsay situations. One example situation is as follows:

You are studying abroad. When you were checking your e-mail at school, you find a message from your father about your dog, Ben, which had been missing for a while. "Ben came back yesterday". A friend who was sitting right next to you asks about Ben. "Did they find him?" What would you say to him? (Ishida, 2006;1300)

In this situation, the source of information is from "family," the timing is "immediate," and the addressee is "friend."

\section{4. 1. Groups of Evidentials in Japanese and English}

A variety of evidentials, which indicate that the information being conveyed is hearsay, are used in Japanese language. In this section, I introduce Japanese evidentials that were used in Ishida's study (2006) and provide definitions discussed in the literature. Table 1 shows the groups of Japanese evidentials used in Ishida (2006). 
Table 1

Ishida's Groups of Japanese Evidentials

\begin{tabular}{|l|l|l|}
\hline \multicolumn{1}{|c|}{ Feature } & \multicolumn{1}{|c|}{ Japanese Evidentials } & \multicolumn{1}{c|}{ English } \\
\hline Auxiliaries & $\begin{array}{l}\text { soo da } \\
\text { rashii } \\
\text { yoo da/mitai da }\end{array}$ & $\begin{array}{l}\text { it seems like } \\
\text { it looks like }\end{array}$ \\
\hline $\begin{array}{l}\text { Reported } \\
\text { Speech }\end{array}$ & to itta /kiita/yonda & $\begin{array}{l}\text { I heard } \\
\text { he said } \\
\text { she said }\end{array}$ \\
\hline $\begin{array}{l}\text { Sentence Final } \\
\text { tte }\end{array}$ & $\begin{array}{l}\text { tteems no close equivalents } \\
\text { in English }\end{array}$ \\
\hline Others & $\begin{array}{l}\text { to no koto da } \\
\text { to iu koto da }\end{array}$ & $\begin{array}{l}\text { it is said } \\
\text { modalities expressions. }\end{array}$ \\
\hline $\begin{array}{l}\text { Direct } \\
\text { Statement }\end{array}$ & $\begin{array}{l}\text { modences that do not contain any } \\
\text { (Ishida } 2006)\end{array}$ & \\
\hline
\end{tabular}

(Ishida, 2006)

\section{4. 2. Lexical Evidential: Hearsay $S o o D a^{2}$}

Hearsay soo, is introduced as "predicate + soo da" in the textbook Japanese: The Spoken Language Part 2 (JSL) in Lesson 21A (Jorden and Noda, 1988). The predicate + soo da is translated into English as "X is said to be true" or "I hear that $\mathrm{X}$ is true," which indicates information that was heard (p. 235). Ishida (2006) and McCready and Ogata (2007) also state that hearsay soo is used when speakers intend to mark second-hand information and indicates a pure hearsay evidential. By using hearsay soo, the speaker shows there is no personal commitment between the speaker and interlocutors about the veracity of the utterance that precedes hearsay soo.

$$
\text { Kono pasta wa oishii soo da. }
$$

I heard that this pasta is delicious.

\footnotetext{
${ }^{2}$ In Japanese, there is another soo da, look-like soo $d a$, which combines with the verbal stem, the adjectival root, and some na-nominals, and is translated as "looking as if," "appearing as if," "sounding as if," and "smelling as if". It refers to an inference or a conclusion that is obtained based on the speaker's senses, such as seeing or smelling (Jorden and Noda, 1988), but is not used to imply second-hand information. In this study, looks-like soo da was excluded since it does not appear in Ishida's study.
} 
I heard that it will rain tonight.

These sentences imply that the propositions are hearsay information and speaker's high degree of belief toward the content, i.e., this pasta is delicious and it will rain tonight. In terms of the use of soo da, JSL and researchers do not refer to the pragmatic rules as to whether soo da is used within formal situations or informal.

\section{4. 3. Lexical Evidential: Rashii $^{3}$}

JSL (Jorden and Noda, 1988) provides an English translation for rashii as “something apparently," "actually is X" (p.337). According to Ishida (2006), rashii is used when speakers refer to an unknown fact based on their observations. Rashii also can be used with the speaker's inference according to their observation. McCready and Ogata (2007) explains that "rashii can be used with evidence that comes from an unknown source -that is, evidence whose source is not clear, but which is still sufficient to make the speaker confident of the truth of the propositional evidence like that used for the pure hearsay evidential soo da" (p.155). They also explain that rashii can be used with "hearsay evidence, auditory evidence, internal sensory evidence and evidence from unclear sources" (p.155). Mushin (2001) investigated the use of rashii by Japanese L1 speakers.

Mushin asked native Japanese speakers to listen to the tape-recorded long conversation between two Japanese speakers and to remember the content as much as they could. Following that, she asked them to tell what they remember to other

3 There is another meaning rashii /noun + rashii/, such as onna rashii hito "a person who approaches the stereotype of femininity" (McCready \& Ogata, 2007). I excluded /noun + rashii/ because it indicates the degree of stereotypical resemblance, but does not indicate second-hand information. 
participants who have not heard the original conversation. She then asked that other participants retell what they heard to another participant in narratives. By analyzing the evidentials the speaker produced, she found that rashii is also used when simply conveying second-hand information in a narrative retelling. In this study, rashii is treated as an evidential that has two features, converting pure hearsay and a speaker's inference, (Ishida, 2006; McCready and Ogata, 2007; Mushin, 2001) and categorized separately from hearsay soo da and yoo da/mitai da.

\section{4. 4. Lexical Evidentials: Yoo Da/Mitai Da}

According to JSL (Jorden and Noda, 1988), mitai da is equivalent to English "like X", "seems", "appear to be", "seem like", "look like" (p.322). Yoo da as a noun is translated as "manner", "resemblance", "like" in English (p.323). McCready and Ogata (2007) explain that yoo da/mitai da are used with evidence that is obtained from the speaker's experiences or senses including tactile and visible sources. Ishida (2006) explains yoo da is used when speakers convey their "inference based on some visible, tangible, or audible evidence" (p.1283) obtained from the speakers' senses. One of the differences between yoo da and mitai da pointed out in the literature is a written/spoken one: yoo da tends to be used more in writing and mitai da is used more in speaking (McCready and Ogata, 2007; Jorden and Noda, 1988).

Functions of yoo da and mitai da are similar to other evidentials in terms of containing the nuance that marks the speakers' certainty level about the fact (Ishida, 2006; McCready and Ogata, 2007). When using these evidentials, speakers do not commit fully to the content of utterances due to the lack of evidence to make it solid, but 
assume the utterance is very close to the fact. I put yoo da and mita dai in the same subcategory.

It should be noted that Ishida's original group contains the auxiliary evidentials soo da, rashii, and yoo da/mitai da, all together named as lexical evidentials which imply that the information is second-hand but do not specify how the information was obtained (2006). On the other hand, in this study, in order to examine them in more detail I divided Ishida's lexical group into three groups, hearsay soo da, rashii, and yoo da/mitai da.

\section{4. 5. Reported Speech: To (tte) Kiita, Yonda, and To (tte) Itta}

Reported speech emprises another category of evidential that shows the conveyed information is hearsay. These evidentials mark explicitly how the information is obtained. Ishida (2006) says that reported speech shows that speakers distance themselves from information and offer weak commitment by implying "what is reported is a fact." In general, to is used in formal speech or written language and tte is used in casual speech or spoken language. Such reported speech explicitly indicates the information is second-hand. English equivalents could be "s/he said," "I heard," or "I read" (Ishida, 2006). Ishida (2006) treated these to (tte) kiita, yonda, and itta as one category.

However, Mushin (1998) proposed that "s/he said" and "I heard" are different in terms of "displaced subjectivity and deictic center theory" (p.35). She insisted that uttering second-hand information which does not show speakers' involvement, such as "Peter said 'I had a wind party last Saturday at my home' (p.36)" indicates a perspective of the actual speaker, Peter, rather than the speaker who is actually conveying this 
information. In contrast, sentences containing the actual speaker, such as "I heard Peter had a party last Saturday at his home" present the actual speaker's perspective.

In my research, I divide them into two sub-groups according to Mushin's (1998) study. The first sub-group includes phrases in which the subject is the person who did the act of hearing or reading, usually the speaker him/herself, such as to kiita or to yonda in Japanese and "I heard" or "I read" in English.

(1) Kyoo wa Miki san wa yasumi da to kiita.

I heard that Miki is absent today.

(2) Kinoo kaji ga atta to yonda.

I read that there was a fire yesterday.

(3) Shinbun de kinoo kaji ga attta to yonda.

I read the news there was a fire yesterday in the newspaper.

These sentences indicate that the speaker obtained the information by hearing or reading, but may not show the source of the information. For instance, the information in the first sentence could be obtained by hearing from their mutual friend or listening to a voice message. In this study, only the verbs of the main clause were counted, so the third sentence is also included in this group since it ends with yonda which refers to the action of the speaker.

My second sub-group includes reported expressions in which the subject of the verb of main clause is other than the speaker. Examples are "she said that" or "it says" in English and to itta and to itteta in Japanese. 
(1) Tanaka san ga, kyoo wa miki san wa yasumi da to itta.

Mr. Tanaka said that Miki is absent today.

(2) Shinbun ni kaji no nyuusu ga kaite atta.

In the newspaper, it's written that there was a fire.

There is a clear statement of who said or who told this information and how the speaker

obtained this information—from Mr. Tanaka by hearing. Compared with to (tte) kiita "I heard" or yonda "I read", in this to itta or to kaite atta "s/he said"or "it said (written)" evidential the source of information is usually explicitly articulated. The second sentence is included in this group since it shows that the verb of the main clause does not involve the speaker him/herself.

\section{4. 6. Reported Speech: Tte in the Sentence Final Position}

According to Ishida (2006), tte is used when the speaker reports second-hand information that s/he remembers. It does not contain any inference of the speakers. Tte in the sentence final position is typically used in spoken and causal situations. According to Ishida (2006) and McCready and Ogata (2007), it seems there is no English equivalent for tte in the sentence final position. The difference between the tte within a reported speech sequence, such as tte itta, kiita, yonda and tte in the sentence final position is whether or not a means of acquiring information (e.g. reading) is stated. The verb, such as tte itta, kiita, yonda, marks how the information comes to the speaker more specifically, whether by reading, hearing, etc., while tte in sentence final position does not explicitly mark it. 
(1) Okaasan ga ato ichijikan gurai de kaette kuru tte.

Apparently, his/her mother will be back about an hour.

(2) Okaasan ga ato ichijikan gurai de kaette kuru tte itta.

My mother says that his/her mother will be back about an hour.

(3) Okaasan ato ichijikan gurai de kaette kuru tte kaite atta.

It was written that his/her mother will be back about an hour.

The first example is the case of tte in the sentence final position, clearly indicating that the content is hearsay. The speaker conveys the second-hand information without referring to the source of information explicitly. While, the second and third examples are the cases of reported sequence tte itta "s/he said" and tte kaite atta "was written," which indicate how the information was transmitted, such as the speaker heard or s/he found a memo.

\section{4. 7. Other Evidentials}

There are many other evidentials available to speakers to make information as uncertain and to clarify their epistemic stance. Examples from Ishida's research are toka (de) "saying something like" and to no koto da "I have heard that" (2006). These evidentials are used when the speaker is not sure about the content of the information or when s/he believes the information could be rumor. They also have a function to summarize the information that s/he obtained. 
According to Aoki (1986), the extended predicate $n$ desu can be considered an evidential. Jorden and Noda (1988:178) state that $n$ desu "serves as an explanation by relating what the speaker is saying to something in the real world that is assumed to be known by the person addressed as well" so it indicates a speaker's epistemic stance toward the information. However, neither Ishida (2006) nor McCready and Ogata, (2007) explained $n$ desu as an evidential or linguistic code used when conveying the second-hand information. In this study, $n$ desu is put into the "other evidentials" category instead of as one of the main evidentials under discussion.

In addition to $n$ desu, "I guess," "I think," the question sentences "did you know that," "it's that" are examples of this group in English. In Japanese to omoimasu "I think", to iu kiji wo mitsukemashita "I found the article that", question sentences with tte shitte $r u$ or gozonji desu ka? "do you know?", and $n$ desu are considered to be evidentials.

\section{4. 8. Direct Statement (Production Not Containing Evidentials)}

The last group comprises covert evidentials, which do not contain any evidential expressions. According to Ishida (2006), sentences that do not contain overt evidentials still express the speaker's epistemic stance, such as attitude and judgment, on their knowledge regarding the information being conveyed. For example, when the speaker conveys the hearsay information that a missing dog, Shiro, came back home, to a friend, s/he may say:

(1) Shiro ga kaette kita (yo).

Shiro came back. 
I heard Shiro came back.

The first sentence implies that the content is a fact and is reliable; it serves as evidence of the speaker's absolute confidence in the proposition. Therefore, the sentence without an explicit evidential shows the speaker's confidence in proposition and the degree of reliability/belief. This covert evidential reveals the speaker's stance which shows a strong commitment toward the content. Thus, Ishida includes this direct statement as one of the evidential groups. In my study, I include direct sentences, these which do not have any additional (modality) expressions, in analysis to compare to use of evidentials.

\section{5. Ishida's (2006) Findings}

Analyzing evidentials discussed in previous sections, Ishida (2006) found that JF learners used less evidentials in both English and Japanese than J-speakers. His data showed that JF learners used evidentials 14.0 times on average in 27 situations on average in English and 15.9 times in Japanese, while J-speakers used 24.3 times in the same situations. That is, the frequency of evidentials of JF learners' Japanese evidentials is much closer to their English than to that of J-speakers. Ishida concluded this was due to the learners' transfer effect.

In addition to transfer effect, Ishida (2006) also found an interesting point: reversed transfer effect. Ishida found that the learners used evidentials more often when conveying information to superiors than to friends. That is, certain English utterances by learners of Japanese followed the same tendency of Japanese L1 speakers, instead of 
following English pragmatic rules. However, according to Kamio (2001), this frequent use of evidentials to superiors usually can be seen only in Japanese language but not English. Ishida insisted that there might be the possibility that if learners become more proficient in their TL, they may transfer their TL knowledge back into their L1. It implied that productions of learners of a foreign language might have a transfer effect from their TL to their L1. Ishida's data contained evidence of this reversed transfer effect and that utterances by learners of Japanese may differ from the ones by monolingual English speakers.

\section{6. Kamada's (1990) Study}

Kamada (1990) examined how English L1 speakers use evidentials in Japanese and discussed how the transfer effect affects their productions in Japanese. He analyzed narratives produced by two second-year students, two third-year students and two fourth-year students who are English L1 speakers learning Japanese. He asked them to visit certain people, such as professors at a university, to collect information before interviews, and had them report orally the obtained information in Japanese.

After the interviews, he looked at all utterances that were grammatically correct, grammatically incorrect, and grammatically correct but inappropriate in terms of the use of evidentials. By analyzing inappropriate utterances, he revealed that learners of Japanese tend to omit evidentials such as soo desu "I heard" or to iimashita "s/he said" when conveying hearsay information. Kamada (1990) also suggested that some utterances sound appropriate if they are in English but can be inappropriate in Japanese. Moreover, these inappropriate sentences matched the pragmatic rules suggested in 
Kamio's theory of territory of information, implying that learners are not aware of different pragmatic rules between Japanese and English and, as a result, learners produced inappropriate sentences due to the transfer effects.

In addition to Kamio's theory and learners' transfer effect, Kamada (1990) also indicated that the learners' environment, such as textbooks and the context settings provided in a classroom, would be one of the factors that affects their TL and their use of evidentials. Generally, textbooks introduce simple grammars and structures in the beginning. Kamada insisted that learners have more experience with grammar and sentence structure that are introduced at the beginning and tend to use them comfortably. He furthermore claimed students were using a risk avoidance strategy in his study. Risk avoidance strategy occurs when learners tend to rely on simple expressions in order to avoid making a wrong choice. As a result, learners tend to use simpler forms which may be acceptable, but not the same as L1 speakers would use. Kamada's study showed that the lower level learners of Japanese tend to avoid using evidentials more than the upper level learners and suggested that learners tend to use simpler forms. Without practicing making their choice among a variety of grammar, learners may choose one that is not ungrammatical, but is not the same as what a Japanese L1 speaker would choose. One reason would be that they lack experience using a variety of evidentials in their real lives.

\section{7. Trent's (1998) Study}

Trent (1998) investigated the use of evidentials through cultural perspectives such as preference of directness and indirectness in reporting styles. Her data were comprised of three narratives in Japanese produced by Japanese L1 speakers and four 
narratives in English produced by English L1 speakers. Participants conveyed information about celebrities or places gathered by the third person or an outside source. By analyzing the data, Trent found that Japanese L1 speakers tend to use more evidentials while English L1 speakers who are in America tend to omit evidentials. She then explained that these differences occurred because of cultural preferences in Japanese and English. These evidentials can make utterances sound ambiguous and understated, and this ambiguity and understatement are appreciated in Japanese culture. In contrast, direct form without evidentials is used more often by Americans than Japanese. This can make statements sound confident or express closeness, and they are considered important in American culture in general.

Trent (1998) used Okabe's (1983) literature and insisted that in Japanese language and culture it is preferred to leave room for ambiguity. Okabe explained Japanese ambiguity as "the cultural assumptions of interdependence and harmony [that] require that Japanese speakers limit themselves to implicit and even ambiguous use of words" (p. 34). According to Trent, to make utterances softer rather than assertive, Japanese speakers tend to add other qualifiers, such as sentence particles, modality expressions (such as maybe, probably, etc.) or evidential expressions, and to avoid direct form utterances and make forms of utterance indirect and ambiguous. On the other hand, English speakers seem to prefer directness and immediacy; closeness and intimacy tend to be more appreciated in American culture in general. Trent (1998) indicates that English speakers seek to express some degree of personal involvement.

Trent (1998) suggests that this cultural difference is created by the speakers' literary education. Japanese literary education focuses on summarizing or reporting facts 
whereas in English there is more emphasis on critical thinking. Based on the different educational backgrounds, Japanese and English speakers process the hearsay information differently and communicate in different ways.

\section{8. Thesis Objectives}

This study aims to reveal if cases of omitting evidentials in English and cases of evidentials repeatedly used in Japanese can be found. The study will compare learners' use of evidentials with English and Japanese L1 speakers. It also investigates if there is learners' transfer effect from English to Japanese. Additionally, by looking at learners' utterances closely, analysis reveals which evidentials are difficult for learners to internalize, which has pedagogical implications. The study aims to help enhance our understanding of Japanese evidentials and improve teaching methods when teaching how to convey hearsay information in Japanese.

In the next chapter, I will address what kind of data were collected, its collection methods and the analytical approach of this study. 


\section{CHAPTER 3:}

\section{METHODOLOGY}

\section{1. Design of the Study}

This is a quantitative study examining the use of evidentials used by English L1 learners of Japanese (JF learners) and Japanese L1 speakers (J-speakers). This study first aimed to examine whether learners' language transfer can be seen in use of evidentials in hearsay situations. This study also aimed to find differences in how learner's evidentials are used in Japanese and English and to propose some suggestions for future study and pedagogical implications.

To investigate the use of evidentials in Japanese and English, three types of utterances were compared: JF learners' use of evidentials in Japanese, JF-learners use in English, and J-speakers' use of evidentials in Japanese. Utterances containing evidentials were gathered using the situations used in Ishida's (2006) study. The situations contained certain information conveyed by a person or the media, and the participants were instructed to convey the information to a specified addressee. Ishida incorporated into the situations the following three variables: timing (immediately, a little later, or one day after hearing the information), source of information (family, friends or media), and status of message recipient (equal or superior). After introducing each situation, participants were asked to convey the information based on the situations to an imaginary third person. The JF learners produced utterances in both English and Japanese, while $\mathrm{J}$-speakers were asked to produce their utterances only in Japanese. In addition to these situations, a follow-up interview was conducted to explore participants' inner thoughts 
about the use of evidentials, and to see if they are conscious about differences between Japanese and English.

After collecting and transcribing utterances from situations, JF learners' Japanese (EJ), JF learners' English (EE), and J-speakers' Japanese (JJ) were compared in terms of direct statements and other evidentials. The number of sentences that contain evidentials in each utterance was counted and compared to reveal whether there was a transfer effect. Next, EJ and JJ utterances were compared in terms of the use of Japanese evidentials to identify with which evidentials JF learners struggle.

\section{2. Participants}

Participants in this study were $15 \mathrm{JF}$ learners who are at the third-year level and above, and $12 \mathrm{~J}$-speakers who study at a university in the United States ${ }^{4}$. Four of them have done a study abroad program in Japan either full-year or six months and three of them are half Japanese and half American.

The reason why JF learners were chosen from third-year Japanese and above is that basic Japanese expressions are introduced comprehensively by the third-year Japanese level. All students who were in third-year Japanese, fourth-year Japanese, or graduate programs, received the e-mail about this study (see appendixes B and C), and 15 participants responded to the e-mail. In the recruitment e-mail, JF learners were informed that the research was about evidentials and also asked not to study or review them before

\footnotetext{
4 The original plan was to recruit $20 \mathrm{JF}$ learners and $20 \mathrm{~J}$-speakers. Due to the lack of time, this study could not reach the original estimated number expected, and the numbers of learners and Japanese L1 speakers are different. However, production from fifteen participants generated sufficient tokens of evidentials for a thorough analysis. I collected utterances from L2 JF learners during the winter term in 2016 and from J-speakers in the spring term in 2017.
} 
they performed the tasks. It is not known if JF learners reviewed before the interview or not, but the collected data show the misuse of evidentials.

$\mathrm{J}$-speakers were defined as Japanese students whose native language is Japanese, who have attended and graduated from Japanese high school. In addition to this identification, I accepted only those who were exchange students and who had not been in the United States for more than one year since Japanese speakers who have lived in the United States more than a year may have been influenced by English language and its use. It may be the case that J-speakers studied English at schools such as high school and university in Japan, so they might already have received influence from English. However, it is assumed that they have not experienced English speaking situations on a daily basis; therefore their Japanese is considered to be close to Japanese used in Japan.

\section{3. Procedure of Data Collection and Analysis}

I had each participant come to a study room in the library and read a set of situations where certain information was conveyed by a person or media. The 12 situations are listed in Appendix E. After reading each situation, I asked participants to convey the information based on the situations to an imaginary third person. JF learners produced utterances in both English and Japanese, and J-speakers produced utterances only in Japanese. The reason for collecting JF learners' responses in English, and then Japanese was to see if there is the transfer effect from the learner's L1 language to Japanese language. I compared JF learners' use of evidentials and J-speakers' use in order to find out which evidentials JF learners find challenging. 
As discussed in the literature review chapter, Ishida's (2006) situations incorporated Kamio's (1995) three factors that affect the use of evidentials: the information's reliability, the timing of conveyance, and politeness strategies. They were designed to compare use of evidentials between JF learners and Japanese speakers' and analyze how the three factors affect the speakers' choice of evidentials. Considering these situations, some might think that utterances that people produce in response to constructed situations may not necessarily be what they would actually say in naturally occurring contexts. However, Ishida (2006) explained that they might not be exactly the same productions as the speaker utters in real life, but situations carefully designed to elicit evidentials can show important points, such as the speakers' pragmatic knowledge of the strategies, linguistic knowledge of evidential codes, communicative acts and sociolinguistic knowledge in their L1 and TL. That is, both situational questionnaires and the speakers' choice can reveal their knowledge sufficiently to be reliable.

Each interaction was recorded on an audio recorder and transcribed after the interview. Each research meeting took approximately 20 minutes for JF learners and 15 minutes for J-speakers. Interviews were conducted in a private space with few distractions. This helps to avoid any risk to participants that might prevent them from producing natural utterances.

After these situations, I conducted interviews in English for JF learners and in Japanese for J-speakers to explore participants' inner thoughts about evidentials. I asked participants if they were conscious about differences in terms of the use of evidentials between Japanese and English. The questions used in these interviews are listed in Appendix F. 
To elicit natural utterances from the participants, I did not give corrective feedback. During the performance of the situations, the participants were able to ask questions if they did not understand the situational context or did not come up with Japanese words and phrases that do not come with evidential parts. However, they were not allowed to ask questions about evidentials and the grammar that connects with the evidential parts. None of the participants got any feedback or correction until they provided their answers for all situations and interviews.

The numbers of evidentials were counted and categorized as below. First, learners' ungrammatical utterances were determined from the analysis in order to investigate the use of evidentials using only the grammatically correct utterances. In this study, some situations contained multiple propositions, which may have caused less use of evidentials in learners' productions, such as in situation 4 and 8 (see Appendix E). Situation 4 and 8 contain more than one proposition. When the information was conveyed with two separate sentences, the one sentence that contains the main proposition was the only one counted. For example, situation 4 describes a situation where a participant got a phone call from their mother, and heard about their sister, who has been sick and in the hospital for a while, got a lot better and came out from the hospital. On the next day, they were asked how their sister was doing by their teacher. In these situations, some participants conveyed two pieces of information: "she is doing well" and "she got out of the hospital." In this case, "she is doing well" was considered the main proposition, because "she is doing well" correspond to the question "how is she doing". This proposition can be more compatible as a response to the teacher. The following are examples of English productions by learners: 
(1) I heard she is doing great. She actually got out of the hospital.

(2) She is doing great. I heard she actually got out of the hospital.

The first production is counted as an evidential sentence since the evidential "I heard" is used with the main proposition, while the second one is counted as a direct group since it lacks evidentials in the main proposition.

J-speakers may say:

(1) Yoku natta soo desu. Taiiin shimashita.

I heard she got better. She got out from the hospital.

(2) Yoku narimasita. Taiiin shita soo desu.

She got better. I heard she got out from the hospital.

When utterances containing more than two sentences were found, the main proposition was determined according to the questions. The way of counting the evidentials in Japanese is the same as English. For example, considering the two Japanese sentences above, the first sentence that contains the information "she got better", which respond to the question "how is she doing," is considered the main proposition. The first example, Yoku natta soo desu, is counted as the sentence which contains evidentials, and the second one, Yoku narimashita is categorized as a direct sentence in my study. The maximum total number of counted productions was 144, from 12 situations by 12 
J-speakers while the JF learners produced a total of 180 utterances in Japanese and 180 in English (15 JF learners in 12 situations).

\section{4. Pilot Study}

I conducted a pilot study to see how data collection would work. In the pilot study, I found that there were some problems in Ishida's procedure that I had to address, and modifications had to be made. First, additional vocabulary supplements were added in the situations list for JF learners. During the pilot study, some JF learners had difficulty producing Japanese utterances due to the complexity of some vocabulary, such as "president" or "kidnap." The list of added vocabulary can be found in Appendix E. It seemed that students were not able to focus on evidentials since they already had difficulty in translating situations in Japanese before moving to evidential parts (which usually come at the end in Japanese). To avoid this situation, the additional vocabulary supplements were added on the sheets to allow JF learners to produce their Japanese utterances smoothly and with more focus on evidentials. Also, learners were told that "grammar mistakes and wrong conjugation were not considered in this study" to exclude other obstacles, so that they could focus on evidential parts and feel less nervous thinking about mistakes.

Secondly, I decided to show participants a list of evidentials without providing any explanation before the situations were read to both JF learners and J-speakers. During the pilot study, one student was trying to produce appropriate Japanese sentences focusing more on sentence structure in terms of grammar and vocabulary than on conveying or reporting information. Seeing the list of evidentials enabled the speakers to 
utilize evidentials more readily. Since the aim of this study was to investigate the JF learners' pragmatic knowledge regarding evidentials, not about how JF learners use evidentials in natural conversation, it was deemed acceptable to remind the participants of types of evidentials before they responded to the situations. If the examples were not shown, participants might have hesitated to use certain evidentials that came up in their mind but they were unsure of pronunciation or grammatical features.

To encourage learners to focus on sentence ending rather than remembering vocabulary, some examples were shown before the explanation about the study was given. When I explained the whole study, all participants were told that the main purpose of this study is to study the use of evidentials, such as soo, rashii, and yoo da, to itta, kiita, yonda, tte in Japanese and "it seems like," "it says," "she said," "according to" in English. With this additional instruction, it is assumed that both JF learners and J-speakers had some idea about what evidentials are and the variety of choice before moving to rendering of hearsay tasks. This made it easier to elicit their pragmatic knowledge regarding evidentials in both Japanese and English.

\section{5. 1. Modifications in Places and Names}

In Ishida's study the situations were presented only in English. In this study however, for Japanese L1 speakers, the Japanese version was used. When creating the Japanese situations, some vocabulary were changed in order to make the content more realistic for J-speakers. For example, the person's name: President Clinton, which was used in English questionnaires, was changed to Prime Minister Abe in Japanese. Also, 
English names, such as Jenny and Richard, were changed into Japanese names such as Taro or Miki.

In addition to these minor revisions, in situation 12, the content of information (types of sports and teams) were changed. The original situation in English was:

You were listening to the radio at home at night and you hear about today's women's volleyball game: "UH beat BYU" Next day you go to school and the teacher asks you whether you know the results. How would you tell him? (Ishida, 2006; 1303)

The changes made to situation 12 are as follows:

Yoru, ie de kyoo no yakyuи no nyuusu wo razio de kiite imasu. Hanshin ga Kyojin ni kachimashita. Tsugi no hi, gakkoo ni iku to, sensei ga geemu no kekka wo kiite kimashita. Sensei ni nanto iimasu ka?

You were listening to the radio at home at night and you hear about today's professional baseball game: Hanshin Tigers beat Kyojin Giants. Next day you go to school and the teacher asks you whether you know the results. How would you tell him?

In this Japanese version, Kamio's three factors, the source of information, timing of conveyance, and addressee, have not been changed, but the content of information is changed from "women's volleyball game" in English to "professional baseball game" in Japanese. In a later chapter, the results regarding this change are addressed. This is the only item that contained different information in English and Japanese. 


\section{5. 2. Modification in the Number of Situations}

While Ishida (2006) created 27 situations that incorporated various combinations of the three factors, in this study, only 12 situations were used with both JF learners and J-speakers. These 12 situations were the same as Ishida's situations, but 15 situations were eliminated in order to avoid taking too much time to complete the tasks. It was thought that the participants, being university students, would be busy with their course work and additional activities, such as part time jobs or clubs, so taking as much as 45 minutes might make them uncomfortable and stressed.

Some of the situations that Ishida used in his study are not realistic for most JF learners. That is, the addressee factor includes the three variables of family, friends, and superiors. In Ishida's study, participants were asked to convey information to one of these three types of addressee, both in Japanese and English. However, in the case of JF learners in this study, they usually talk to their parents in English and it is very unlikely that they speak to their parents in Japanese. Due to this reason, "family" was eliminated in my study. In addition, "a little bit later", the factor of timing, was also eliminated because Ishida's study (2006) did not show any outstanding differences for this factor. Kamio's theory of territory of information, which Ishida used as a theoretical foundation, also did not mention how much time is needed to process the information. This study compared two timings from Ishida's study: "immediately" and "the day after" to look for differences in production.

Cutting two variables (one from the addressee factor and one from the timing factor) resulted in a total of 12 situations. By excluding 15 unrealistic situations, the total number of time became about 15 to 20 minutes. 


\section{5. 3. Modifications in Groups of Evidentials}

In Ishida's study (2006), evidentials were divided into five groups: auxiliaries, reported speech, tte in the sentence final position, other evidentials, and without evidentials (see Table 1). In this study, his group was modified, and evidentials were divided into nine groups in order to identify which type of evidentials is problematic for JF learners. Table 2 presents the categorization of evidentials used in my study. For lexical evidentials, while Ishida categorized hearsay soo da, rashii and yoo da/mitai da in the same group as auxiliary evidentials, I divided them into three, hearsay soo $d a$, hearsay and inference rashii, and inference yoo da/mitai da. When conveying hearsay information, hearsay soo da is used to convey pure hearsay information, and yoo da/mitai $d a$ is more focused on the speaker's inference regarding what they heard (Ishida, 2006; McCready and Ogata, 2007; Mushin, 2001). According to Mushin (2001), rashii is categorized separately in this study since rashii can be used for both conveying pure hearsay information and the speaker's inference according to what they heard.

In addition to lexical evidentials, the categories of reported evidentials were modified in this study. While Ishida (2006) put to kiita "I head", to yonda "I read" and to itta "s/he said" in one and this study grouped to kiita, and to yonda in another. They are different in terms of the subject of sentence while the former indicates the subject is the speaker who did the act of hearing or reading, the latter indicates the subject is other than the speaker such as the person from whom the speaker received the original information.

Ungrammatical sentences were categorized under the "ungrammatical" category. There are some expressions that cannot be placed in any group because they are either ungrammatical or uncountable due to lack of information. In my study, ungrammatical 
and uncountable expressions include to iu yoo ni itta, to itta soo desu, and to kiita soo

desu.

Table 2

The Groups of Evidentials

\begin{tabular}{|c|c|c|c|}
\hline \multicolumn{2}{|c|}{ Feature } & Japanese Evidentials & \multirow{4}{*}{\begin{tabular}{|l|}
\multicolumn{1}{|c|}{ English } \\
apparently \\
it seems \\
it looks like
\end{tabular}} \\
\hline \multirow[t]{3}{*}{$\begin{array}{l}\text { Lexical } \\
\text { Evidentials }\end{array}$} & Hearsay & $\begin{array}{l}\text { soo da } \\
\text { Ame ga furu soo da. } \\
\text { "(I heard) it will be rain." }\end{array}$ & \\
\hline & $\begin{array}{l}\text { Hearsay or } \\
\text { speaker's } \\
\text { Inference }\end{array}$ & $\begin{array}{l}\text { rashii } \\
\text { Ame ga furu rashii. } \\
\text { "Apparently it will be rain." }\end{array}$ & \\
\hline & $\begin{array}{l}\text { Speaker's } \\
\text { Inference }\end{array}$ & $\begin{array}{l}\text { yoo da, mitai da } \\
\text { Ame ga furu yoo da/ mitai da. } \\
\text { "It seems it will be rain." }\end{array}$ & \\
\hline \multirow[t]{3}{*}{$\begin{array}{l}\text { Reported } \\
\text { Evidentials }\end{array}$} & $\begin{array}{l}\text { Subject is } \\
\text { the speaker } \\
\text { who did the } \\
\text { act of } \\
\text { hearing or } \\
\text { reading }\end{array}$ & $\begin{array}{l}\text { to (tte) kiita/yonda } \\
\text { Ame ga furu to kiita. } \\
\text { "I heard it will be rain." }\end{array}$ & $\begin{array}{l}\text { I heard } \\
\text { I read }\end{array}$ \\
\hline & $\begin{array}{l}\text { Subject is } \\
\text { other than } \\
\text { speaker }\end{array}$ & $\begin{array}{l}\text { S.B. ga X to itta/ S.T. ni X to } \\
\text { kaiteatta } \\
\text { Tanaka-san ga ame ga furu to itta. } \\
\text { "Mr. Tanaka said it will be rain." }\end{array}$ & $\begin{array}{l}\text { he said } \\
\text { she said } \\
\text { it said }\end{array}$ \\
\hline & $\begin{array}{l}\text { Unclear } \\
\text { Source }\end{array}$ & $\begin{array}{l}\text { tte } \\
\text { Ame ga furu tte. } \\
\text { "It will be rain (they said)." }\end{array}$ & $\begin{array}{l}\text { tte may not } \\
\text { have no English } \\
\text { linguistic } \\
\text { element that } \\
\text { correspond to } \\
\text { the use of tte }\end{array}$ \\
\hline \multicolumn{2}{|c|}{$\begin{array}{l}\text { Other Productions that do } \\
\text { not belong to any groups }\end{array}$} & $\begin{array}{l}\text { to omou, tte shitteru? } \\
\text { n desu etc. } \\
\text { Amega furu to omou. } \\
\text { "I think it will be rain." } \\
\text { Amega furu tte shitteru? } \\
\text { "Do you know it will be rain?" }\end{array}$ & $\begin{array}{l}\text { I guess } \\
\text { did you know } \\
\text { it's that, etc. }\end{array}$ \\
\hline \multicolumn{2}{|c|}{ Direct Statement } & $\begin{array}{l}\text { Sentences that do not contain any } \\
\text { of the evidentials described above. }\end{array}$ & \\
\hline
\end{tabular}


Result of the use of evidentials by J-speakers and JF learners will be presented in the next chapter. I will discuss the results in relation to factors causing pragmatic transfer effect that have been discussed in the literature. 


\section{CHAPTER 4:}

\section{RESULTS AND DISCUSSION}

In this chapter, the results of the data are discussed with six tables. These tables are presented to show the number of productions that contain varieties of evidentials, other evidentials, such as to omou "I think" or tte shitteru "Do you know X?", and direct statements that do not contain any evidentials. In the tables, JJ refers to Japanese productions by Japanese speakers (J-speakers), EJ refers to Japanese productions by English L1 speakers who learn Japanese (JF learners), and EE refers to English productions by JF learners.

Evidentials appearing at the end of the main proposition sentence part were counted and categorized into each type. The total number of $\mathrm{JJ}$ is 144, produced from 12 situations by 12 participants, and each of the total number of productions of EJ and EE are 180, produced from 12 situations by 15 participants. Since the total number of $\mathrm{J}$-speakers and JF learners are different, the differences are shown in percentages.

\section{1. Learners' Transfer Effect}

This section presents the results concerning the research question: is there any transfer effect in EJ learners' production regarding evidential use? In order to indicate transfer effects, evidentials of the three productions, JJ, EJ and EE, were compared. Table 3 shows the frequency of the use of evidentials by J-speakers in Japanese and English in $\mathrm{JF}$ learners. When JJ and EE are compared, the study shows less frequent use of direct productions in $\mathrm{JJ}$ than $\mathrm{EE}(\mathrm{JJ}=79.9 \%, \mathrm{EE}=61.1 \%)$. This indicates that $\mathrm{JF}$ learners used fewer evidentials in English than J-speakers. Next, when JJ and EJ are compared, the data 
shows more frequent use of evidentials in $\mathrm{JJ}$ than $\mathrm{EJ}$ as well $(\mathrm{JJ}=79.9 \%$, EJ=66.1\%). This supports that JF learners use fewer evidentials in Japanese than native Japanese speakers. Next, when EJ and EE are compared, it shows more frequent use of evidentials in EJ than $\mathrm{EE}(\mathrm{EJ}=66.1 \%, \mathrm{EE}=61.1 \%)$.

Comparing these three productions $(\mathrm{JJ}=79.9 \%, \mathrm{EJ}=66.1 \%, \mathrm{EE}=61.1 \%)$, it can be shown that the JF learners used less evidentials in both Japanese and English than J-speakers, and moreover, the percentage of EJ is closer to EE than JJ. That is, the gap between $\mathrm{JJ}$ and $\mathrm{EJ}$ is $13.8 \%$ while $\mathrm{EJ}$ and $\mathrm{EE}$ is $5.0 \%$. Learners' Japanese productions are much closer to their English than J-speakers production in terms of the numbers of used evidentials. It implies that learners' English pragmatic knowledge affects their Japanese productions to some degree, resulting in the less frequent use of evidentials in JJ.

However, when EJ and EE are compared, JF learners used evidentials more frequently in Japanese $(\mathrm{EJ}=66.1 \%, \mathrm{EE}=61.1 \%)$. This implies that JF learners, at least, tend to apply Japanese evidentials' pragmatic rules to some degree. 
Table 3

The Frequency of the Use of Evidentials

\begin{tabular}{|c|c|c|c|}
\hline & $\begin{array}{c}\text { Native Japanese } \\
\text { speaker's production } \\
\text { in Japanese (JJ) }\end{array}$ & $\begin{array}{c}\text { Native English } \\
\text { speakers' production } \\
\text { in Japanese (EJ) }\end{array}$ & $\begin{array}{c}\text { Native English } \\
\text { speakers' production } \\
\text { in English (EE) }\end{array}$ \\
\hline Evidentials & $\begin{array}{c}79.9 \% \\
(115)\end{array}$ & $\begin{array}{c}66.1 \% \\
(119)\end{array}$ & $\begin{array}{c}61.1 \% \\
(110)\end{array}$ \\
\hline Direct & $\begin{array}{c}16.0 \% \\
(23)\end{array}$ & $\begin{array}{c}25.0 \% \\
(45)\end{array}$ & $\begin{array}{c}33.9 \% \\
(61)\end{array}$ \\
\hline Others & $\begin{array}{c}4.2 \% \\
(6)\end{array}$ & $\begin{array}{c}4.4 \% \\
(8)\end{array}$ & $\begin{array}{c}5.0 \% \\
(9)\end{array}$ \\
\hline Ungrammatical & N/A & $4.4 \%$ & N/A \\
\hline Total & 144 & 180 & 180 \\
\hline
\end{tabular}

This table shows the possibility of learner's transfer effect. In the next section, Kamio's three factors that may affect the use of evidentials will be discussed.

\section{2. 1. Kamio's Three Factors}

This section discusses results related to Kamio's three factors in Japanese:

relationships between the reliability of information, timing of conveyance, and politeness strategy. Comparing productions in JJ, EJ and EE reveals whether JF learners internalize these pragmatic rules in Japanese and whether they follow them. It should be noted that situation 12 in which the Japanese version of content was different from Ishida's study (see p.32), created big differences. From this section, the tables exclude situation 12 so that they can be compared with Ishida's original data ${ }^{5}$.

Tables 4, 5 and 6 show the number of evidentials used in relation to Kamio's three factors. The total amount of $\mathrm{JJ}$ productions is 122 , produced by $12 \mathrm{~J}$-speakers from

5 The results on situation 12 will be discussed in a separate section (see p.37). 
eleven situations. The total number of EJ and EE is 165 , produced by $15 \mathrm{JF}$ learners from 11 situations. Percentages show differences in JJ, EJ and EE.

\section{2. 2. The Source of Information}

The first factor is the reliability of the information. According to Kamio (1995), when English L1 speakers convey reliable information in English, they may omit evidentials. In Japanese, however, the reliability of information does not affect the presence of evidentials. Ishida made an assumption that the information from friends or family would have a higher degree of reliability than from media. However, Ishida's study (2006) did not explain the reason of this order of reliable sources (friends or family

$>$ media), nor show much difference between the three sources of information. However, in this study, it was found that JF learners tended not to use evidentials when conveying information obtained from media.

Table 4 shows the total frequency of the use of evidentials for JJ, EJ, and EE in relation to the source of information; family, friend, and media. 
Table 4

Total Frequency of the Use of Evidentials Depending on the Source of Information without Situation 12

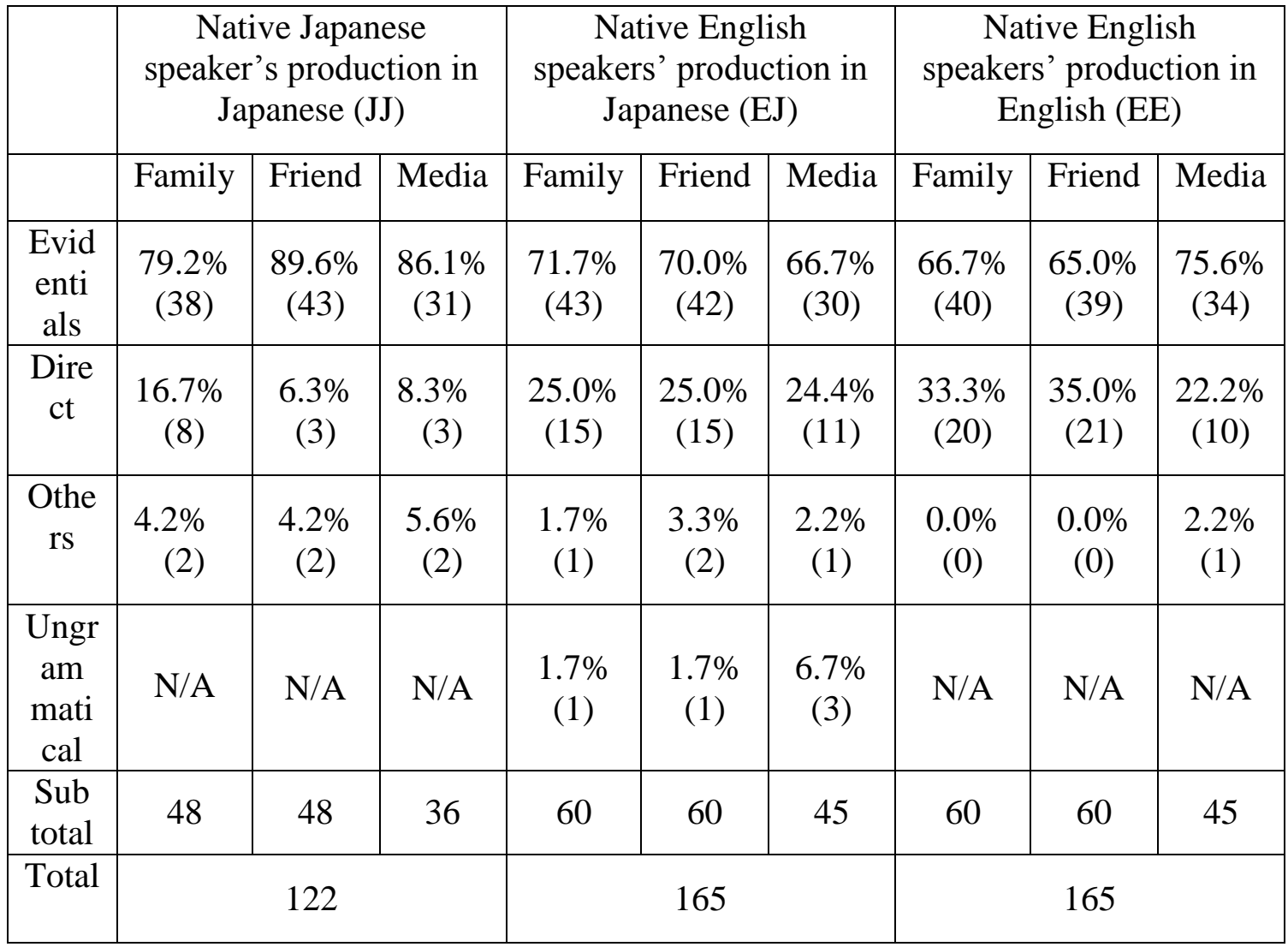

In this study, when comparing evidentials in EE, there was a difference found that correlated to the source of information. JF learners tended to use evidentials when conveying information obtained from family and friends less often than from media (family $=66.7 \%$, friend $=65.0 \%$, media $=75.6 \%$ ) in English. In addition, when JF learners were asked the question, "does the use of evidentials differ depending on the source of information-friends or media, such as the internet and TV?" all learners answered that they were different and said that the reliability of the information matters when deciding on use of evidentials. However, when JF learners were asked to rank these three sources, they could not rank them clearly. Regarding the information from the media, some 
learners mentioned that it is hard to say whether information from the media has high reliability or not. The reliability of information cannot be determined only by knowing the source of information, and the speaker needs to have more details regarding the quality of the information. From the JF learners' answers in the follow-up interviews, it can be said that when considering the reliability of information, other points should be considered as well, such as how much detailed information was on the news, whether the news was covered in several pages with pictures or just a few sentences with a short headline.

Additionally, in terms of the source of information, speakers may consider which companies provided the information, whether it was from well-known and reliable companies, such as BBC or the New York Times, or just random university radio. It may not be plausible to assume that all information obtained from the media or radio has the same degree of reliability. Ishida may need to modify his assumption that information obtained from the media has a low degree of reliability so that JF learners use less evidentials. It may help to get more accurate data if situations provide more details of the quality of the information.

Differences in the use of evidentials in relation to the source of information could also be seen in $\mathrm{JJ}$ (family $=79.2 \%$, friend $=89.6 \%$, media=86.1\%). $\mathrm{J}$-speakers used evidentials more often when the information was obtained from a friend or the media as compared to family. Kamio did not mention specifically which sources may have higher reliability than others in his theory, although this result shows that the information from family contains less evidentials than from friend or media. According to Kamio's theory, this implies that, the information that the speaker obtained from family could be the most 
reliable among these three, since use of evidentials differs depending on the source of the information and its reliability ${ }^{6}$. However, when comparing the information from friend and media in $\mathrm{JJ}, \mathrm{J}$-speakers use more evidentials with the information from friends (friend $=89.6 \%$, media $=86.1 \%$ ). Future studies should address this result along with how the speaker treats media information regarding the use of evidentials.

\section{2. 3. Timing of Conveyance}

Kamio (1995) stated that if sufficient time has passed, information is processed to become the speaker's own information and can be conveyed without evidentials in Japanese, but the timing does not affect use of English evidentials. Ishida's data showed that $\mathrm{J}$-speakers used less evidentials when conveying information on the following day. In this study, about $3.4 \%$ difference in relation to the timing and evidentials can be found in J-speakers' utterances (immediate $=83.3 \%$, one day after $=86.7 \%$ ), which does not conform to Kamio's theory. Furthermore, when comparing direct statements in JJ (immediate $=11.1 \%$, one day after $10.0 \%$ ) remarkable differences cannot be seen, while "others" show a $2.3 \%$ difference (immediate $=5.6 \%$, one day after=3.3\%).

Table 5 shows the total frequencies of the use of evidentials by the timing of conveyance, immediate and a day after, excluding situation 12 :

\footnotetext{
${ }^{6}$ As explained on p.27, these situations include three different factors in each one so it is difficult to know which factors affect the use of evidential the most. For future study, situations need to be modified to investigate each factor, such as by making situations that contain only one factor in each situation.
} 
Table 5

Total Frequency of the Use of Evidentials Depending on Timing of Conveyance without Situation 12

\begin{tabular}{|c|c|c|c|c|c|c|}
\hline & \multicolumn{2}{|c|}{$\begin{array}{l}\text { Native Japanese } \\
\text { speaker's production } \\
\text { in Japanese }(\mathrm{JJ})\end{array}$} & \multicolumn{2}{|c|}{$\begin{array}{l}\text { Native English } \\
\text { speakers' production } \\
\text { in Japanese }(\mathrm{EJ})\end{array}$} & \multicolumn{2}{|c|}{$\begin{array}{l}\text { Native English } \\
\text { speakers' production } \\
\text { in English }(\mathrm{EE})\end{array}$} \\
\hline & $\begin{array}{l}\text { Immediat } \\
\mathrm{e}\end{array}$ & $\begin{array}{c}\text { One day } \\
\text { After }\end{array}$ & $\begin{array}{l}\text { Immediat } \\
\mathrm{e}\end{array}$ & $\begin{array}{c}\text { One day } \\
\text { After }\end{array}$ & $\begin{array}{c}\text { Immediat } \\
\mathrm{e}\end{array}$ & $\begin{array}{c}\text { One day } \\
\text { After }\end{array}$ \\
\hline $\begin{array}{l}\text { Evide } \\
\text { ntials }\end{array}$ & $\begin{array}{c}83.3 \% \\
(60)\end{array}$ & $\begin{array}{c}86.7 \% \\
(52)\end{array}$ & $\begin{array}{c}72.2 \% \\
(65)\end{array}$ & $\begin{array}{c}69.3 \% \\
(52)\end{array}$ & $\begin{array}{c}66.7 \% \\
(60)\end{array}$ & $\begin{array}{c}65.3 \% \\
(49)\end{array}$ \\
\hline $\begin{array}{c}\text { Direct } \\
\text { Statement }\end{array}$ & $\begin{array}{c}11.1 \% \\
(8)\end{array}$ & $\begin{array}{c}10.0 \% \\
(6)\end{array}$ & $\begin{array}{c}22.2 \% \\
(20)\end{array}$ & $\begin{array}{c}26.7 \% \\
(20)\end{array}$ & $\begin{array}{c}33.3 \% \\
(30)\end{array}$ & $\begin{array}{c}34.7 \% \\
(26)\end{array}$ \\
\hline Others & $\begin{array}{c}5.6 \% \\
(4)\end{array}$ & $\begin{array}{c}3.3 \% \\
(2)\end{array}$ & $\begin{array}{c}2.2 \% \\
(2)\end{array}$ & $\begin{array}{c}1.3 \% \\
(1)\end{array}$ & $\begin{array}{l}0 \% \\
(0)\end{array}$ & $\begin{array}{c}1.3 \% \\
(1)\end{array}$ \\
\hline $\begin{array}{l}\text { Ungram } \\
\text { matical }\end{array}$ & N/A & N/A & $\begin{array}{c}3.3 \% \\
(3)\end{array}$ & $\begin{array}{c}2.7 \% \\
(2)\end{array}$ & N/A & N/A \\
\hline Subtotal & 72 & 50 & 90 & 75 & 90 & 75 \\
\hline Total $^{\top}$ & \multicolumn{2}{|c|}{122} & \multicolumn{2}{|c|}{165} & \multicolumn{2}{|c|}{165} \\
\hline
\end{tabular}

When looking at JJ's production, it does not show a huge difference in the use of evidentials between the conveyance of immediately or one day after (immediate $=83.3 \%$, one day after $=86.7 \%$ ), which does not support Kamio's theory. When comparing JF learners' use of evidentials between "immediate" and "one day after," in EJ, the decrease of the evidentials from the immediate to one day after was very small (immediate $=72.2 \%$, one day after $=69.3 \%$ in EJ). It can be concluded that JF learners were not aware of the pragmatic rules about the timing of conveyance as argued by Kamio's theory.

When the follow-up question "Does the use of evidentials differ depending on when you convey information: immediate or one day after?” was asked to J-speakers,

\footnotetext{
${ }^{7}$ Productions of this table were elicited from twelve J-learners and fifteen JF learners; the total amount of $\mathrm{JJ}$ is 122 , produced by J-speakers, and both EJ and EE are 165, produced by $15 \mathrm{JF}$ learners from eleven situations. Each total is divided into two types of timing: immediate and a day after, which is the same as Ishida's study. Since the productions excluded situation 12 that dealt with the information obtained from "a day after", the total of "a day after" production is 50 and 75 in JJ and EJ/EE respectively while the total of "immediate" is 72 and 90.
} 
only three out of twelve J-speakers stated that they might not use any evidentials when conveying the information one day after. They explained that they might use either the direct form or make sentences in question form, such as Abe souri ga jiko ni atta tte kiita? "Did you hear that the President Abe got an accident?," since they assumed that the information has been already disseminated, especially with easy access to the internet. In contrast, when the same follow-up question was asked to JF learners, most of the JF learners responded that they do not differ, or that they may add the date when they heard the information, such as, "Yesterday, I heard that Prime Minister Abe got in an accident." None of them mentioned Kamio's factor that in Japanese the speakers may omit evidentials when conveying the information if sufficient time has passed. This may imply the lack of learner's pragmatic knowledge in relation to timing ${ }^{8}$.

The results regarding the timing of conveyance in this study does not support Kamio's theory about timing in J-speakers' utterances, however the follow-up question revealed that decreased use of evidentials is not the only feature that indicates internalization of second-hand information. The possible reason could be that their utterances responded to the situations might be influenced by other factors, such as the relation to the speaker's involvement with the content of the information or addressees. That is, the speaker may not consider timing as much as other factors. This suggests that in order to investigate pragmatic knowledge of the timing, other research methods may be more effective, such as conducting interviews and collecting natural discourse or recording natural conversation between Japanese speakers.

\footnotetext{
${ }^{8}$ Some may argue that JF learners might be more aware of Kamio's pragmatic rules in Japanese due to the numbers shown in Table 5. However, in this study, it was assumed that JF learners were not aware of the rule according to the learners' answers from the follow-up questions.
} 


\section{2. 4. Addressees}

This section aims to find out which evidentials learners are aware of and when they internalize pragmatic rules in terms of politeness. Kamio (1997) proposed that J-speakers tend to use more evidentials to make his/her sentence softer when conveying information, but English speakers do not apply this softening politeness strategy. To see the differences in relation to evidentials and politeness strategy, Ishida (2006) created situations that asked participants to convey the information to either the speaker's superior or friend. Ishida's assumption was that when conveying the information J-speakers use evidentials to superiors more often than to friends. His data showed that JF learners used evidentials more frequently with superiors than with friends. Moreover, the use of evidentials to both friends and superiors were more frequent in EE than in EJ, based on which he suggested reversed pragmatic transfer. In this study, JF learners used more evidentials both in EJ (friend=66.7\%, superior=76.0\%) and EE (friend $=57.8 \%$, superior $=74.7 \%$ ) to friend than to superior, while $\mathrm{JJ}$ is opposite (friend $=88.95$, family $=80.0 \%$ ). Table 6 shows the total frequencies of the use of evidentials depending on the addressee: 
Table 6

Total Frequency of the Use of Evidentials Depending on Addressee without Situation 12

\begin{tabular}{|c|c|c|c|c|c|c|}
\hline & \multicolumn{2}{|c|}{$\begin{array}{c}\text { Native Japanese } \\
\text { speaker's production } \\
\text { in Japanese (JJ) }\end{array}$} & \multicolumn{2}{c|}{$\begin{array}{c}\text { Native English } \\
\text { speakers' production } \\
\text { in Japanese (EJ) }\end{array}$} & \multicolumn{2}{c|}{$\begin{array}{c}\text { Native English } \\
\text { speakers' production } \\
\text { in English (EE) }\end{array}$} \\
\hline Friend & Superior & Friend & Superior & Friend & Superior \\
\hline Evidentials & $\begin{array}{c}88.9 \% \\
(64)\end{array}$ & $\begin{array}{c}80.0 \% \\
(48)\end{array}$ & $\begin{array}{c}66.7 \% \\
(60)\end{array}$ & $\begin{array}{c}76.0 \% \\
(57)\end{array}$ & $\begin{array}{c}57.8 \% \\
(52)\end{array}$ & $\begin{array}{c}74.7 \% \\
(56)\end{array}$ \\
\hline $\begin{array}{c}\text { Direct } \\
\text { Statement }\end{array}$ & $\begin{array}{c}11.1 \% \\
(8)\end{array}$ & $\begin{array}{c}10.0 \% \\
(6)\end{array}$ & $\begin{array}{c}28.9 \% \\
(26)\end{array}$ & $\begin{array}{c}18.7 \% \\
(14)\end{array}$ & $\begin{array}{c}41.1 \% \\
(37)\end{array}$ & $\begin{array}{c}25.3 \% \\
(19)\end{array}$ \\
\hline Others & $\begin{array}{c}0.0 \% \\
(0)\end{array}$ & $\begin{array}{c}10.0 \% \\
(6)\end{array}$ & $\begin{array}{c}1.1 \% \\
(1)\end{array}$ & $\begin{array}{c}2.7 \% \\
(2)\end{array}$ & $\begin{array}{c}1.1 \% \\
(1)\end{array}$ & $\begin{array}{c}0.0 \% \\
(0)\end{array}$ \\
\hline ungrammatical & N/A & N/A & $\begin{array}{c}3.3 \% \\
(3)\end{array}$ & $\begin{array}{c}2.7 \% \\
(2)\end{array}$ & N/A & N/A \\
\hline Subtotal & 72 & 50 & 90 & 75 & 90 & 75 \\
\hline Total & \multicolumn{2}{|c|}{122} & \multicolumn{2}{c|}{165} & \multicolumn{2}{|c|}{165} \\
\hline
\end{tabular}

The data, comparing JJ's friends and superior shows the J-speakers' less frequent use of evidentials to superiors (friend $=88.9 \%$, superior $=80.0 \%$ ). However, when looking at direct statements, it does not show much differences (friend $=11.1 \%, 10.0 \%$ ). Additionally, when looking at other categories, the data suggests that when J-speakers convey the information to superiores, they may use other expressions such as to omou "I guess" or a question form like a proposition and gozonji desu ka "do you know?" In terms of the number of indirect statements, this data does not confirm Kamio's theory and Ishida's assumption that speakers use evidentials more frequently to superiors in Japanese. However, this study revealed that J-speakers might not use evidentials but, perhaps instead, use other expressions to soften utterances as a politeness strategy.

\footnotetext{
${ }^{9}$ Productions of this table are elicited by twelve J-learners and $15 \mathrm{JF}$ learners. The total amount of JJ is 122 , produced by J-speakers, and both EJ and EE are 165, produced by $15 \mathrm{JF}$ learners from eleven situations. Each total is divided into one of two types of addressee: friend or superior, which is the same as Ishida's study. Since the productions excluded situation 12, which used "superior," the total of "superior" production is different from the other two-minus 12 in $\mathrm{JJ}$ and minus 15 in EJ and EE.
} 
When we look at JF learners' use of evidentials, we see they used evidentials more often to superiors than to friends both in Japanese (friend $=66.7 \%$, superior $=76.0 \%$ ) and English (friend $=57.8 \%$, superior $=74.4 \%$ ). According to this data, JF-learners followed Kamio's theory and Ishida's assumption. There are some possible factors that explain why these results appeared in this study: 1) reversed transfer effect, which may explain learners' unusually high production of evidentials in English, and 2) J-speakers' lack of politeness strategy, which may be related to age or inexperience in work scenarios.

\section{2. 5. Reversed Transfer Effect}

The politeness strategy in Kamio's theory (1995) proposes that Japanese speakers tend to produce sentences with evidentials to superiors in order to make sentences softer, but this strategy does not apply to English. However, Table 9 shows that in EE, JF learners use evidentials $15 \%$ more often to superiors than to friends (friend $=57.8 \%$, superior $=74.7$ ). This implies that JF learners might have been influenced by Japanese politeness strategies in their L1. The learning environments of the TL might influence their L1. For example, the JF learners in this study were in a Japanese program that utilized the performed culture approach. In this method, instructors attempt to teach not only Japanese language, but also Japanese culture in terms of how Japanese people speak and act, and how to communicate to make Japanese people comfortable (Christensen \& Warnick, 2006). In this teaching approach, instructors often discuss politeness and formality in Japanese classes was well as create contexts in which learners enact politeness strategies. JF learners might have become more sensitive 
toward addressees and exhibit that sensitivity, even when speaking in their L1. For future studies, in order to avoid the influence of this reversed transfer effect, it would be better to collect data from participants who do not speak a foreign language and, therefore, have presumably not been influenced with pragmatic knowledge of other languages.

\section{2. 6. J-Speakers' Less Use of Evidentials with Superior}

As shown in Table 6, J-speakers used more evidentials toward friends than superiors (friend $=88.9 \%$, superior $=80.0 \%$ ). Most of the $\mathrm{J}$-speakers were university students who did not have experience working as professionals, so they may not be familiar with applying politeness strategies in their daily lives when speaking to superiors with whom they should care about maintaining good relationships, such as a boss or business partners. The result may be different if participants included different groups of J-speakers who have graduated from school and have work experience. It should be noted that J-speakers used "other expressions" to a superior 10\% more than to a friend (friend $=0.0 \%$, superior $=10.0 \%$ ) and the number of direct statements is very similar between the two addressees (friend $=11.1 \%$, superior $=10.0 \%$ ). That is, J-speakers used not

only evidentials, but also other phrases in order to avoid direct sentences when conveying information to a superior.

In his study, Ishida (2006) did not mention his participants' background information, except their L1 language, so the backgrounds of the participants, such as their work experience and expertise, were not taken into consideration. Future studies need to address these points in order to analyze in more detail. 


\section{2. 6. Other Possible Factors from Kamio's Theory and Evidential Use}

This section discusses whether there are factors that affect the use of evidentials other than the three factors, the reliability of the information, the timing, and the addressee, mentioned in Kamio's theory. As discussed in Chapter 3, the contents of situation 12 are slightly different in Japanese and English. The number of evidentials in situation 12 shows significant differences between JJ, EJ and EE in relation to direct statements $(\mathrm{JJ}=75.0 \%, \mathrm{EJ}=33.3 \%, \mathrm{EE}=33.3 \%)$. The differences led to exploration of other factors that might have affected evidential use.

In situation 12, the participant was asked the question whether they know the result of a sports match by the teacher. They heard the results from a radio sports news broadcast the night before. In the original situation used in Ishida's (2006) study, the context of information was “women's volleyball game” in English, but this study used "professional baseball game" in Japanese. Table 7 shows the frequency of the use of covert evidentials in situation 12. In this section, the number of the total is the ratio of productions to situation uttered by $12 \mathrm{~J}$-speakers and $15 \mathrm{JF}$ learners. 
Table 7

The Frequency of the Use of Evidentials in Situation 12

\begin{tabular}{|c|c|c|c|}
\hline & $\begin{array}{c}\text { Native Japanese } \\
\text { speaker's } \\
\text { production in } \\
\text { Japanese (JJ) }\end{array}$ & $\begin{array}{c}\text { Native English } \\
\text { speakers' } \\
\text { production in } \\
\text { Japanese (EJ) }\end{array}$ & $\begin{array}{c}\text { Native English } \\
\text { speakers' } \\
\text { production in } \\
\text { English (EE) }\end{array}$ \\
\hline Evidentials & $\begin{array}{c}25.0 \% \\
(3)\end{array}$ & $\begin{array}{c}60.0 \% \\
(9)\end{array}$ & $\begin{array}{c}66.7 \% \\
(10)\end{array}$ \\
\hline $\begin{array}{c}\text { Direct } \\
\text { Statement }\end{array}$ & $\begin{array}{c}75.0 \% \\
(9)\end{array}$ & $\begin{array}{c}33.3 \% \\
(5)\end{array}$ & $\begin{array}{c}33.3 \% \\
(5)\end{array}$ \\
\hline Others & $0.0 \%$ & $\begin{array}{c}6.7 \% \\
(1)\end{array}$ & $\begin{array}{c}0.0 \% \\
(0)\end{array}$ \\
\hline Ungrammatical & $(0)$ & 0 & N/A \\
\hline Total & 12 & 15 & 15 \\
\hline
\end{tabular}

As shown in this table, evidentials were used more often in EJ and EE

$(\mathrm{EJ}=60.0 \%, \mathrm{EE}=66.7 \%)$ than $\mathrm{JJ}(25.0 \%)$ in situation 12 , and this result is opposed to the hypothesis, that is, evidentials are used less often by JF learners than J-speakers. In situation 12, the three factors, timing, addressee, and source, remain the same in English and Japanese. However, productions of JJ as compared to EJ and EE, showed a remarkable difference. This implies that the use of evidentials and productions are determined by not only Kamio’s three factors, reliability of information, timing of conveyance, and politeness strategy, but also the content of information and its relation to the speaker's involvement in the content ${ }^{10}$.

Kamio (1995) insists that sentence ending forms may differ depending on the speaker's expertise, such as a specialized field or residence in a particular geographical

\footnotetext{
${ }^{10}$ Each situation used in Ishida's study and this study contain three factors, reliability of the information, timing, and addressees, and it is hard to know the degree of how and which factor the speaker considered the most from the situational task.
} 
location, in both Japanese and English ${ }^{11}$. He explains when the hearer is intended to have less information, "experts can use the direct form in conveying information within their fields of expertise to hearers with no special training in those fields" (p.76). For example, even though a speaker does not have any personal geographical relation between Tokyo and themselves, if they are experts of demography or a geographer, they may convey the information without evidentials, such as:

\section{Tokyo no jinkoo wa 13,700,000 nin gurai desu yo.}

The population of Tokyo is approximately 13,700,000.

While Kamio explained that the speaker's expertise affects the use of evidentials, this study suggests that the speaker's personal interest and involvement in content should be considered. For instance, some J-speakers may have been a big fan of baseball, and their involvement in this context is strong. In this case, their active involvement in the speaker as a fan may enable them to omit evidentials, and thus show their strong connection toward the proposition. This suggests a modification of Kamio's theory, that is, the degree of the speaker's personal interest and involvement should be considered, as well as expertise.

\footnotetext{
${ }^{11}$ In Kamio's theory of territory of information, the amount of information that a speaker and hearer has affect the sentence form. This usually applies when the speaker (expert) gives presumably new information to the hearer.
} 


\section{3. 1. Use of Evidentials According to Different Groups}

This section presents the different use of evidentials in Japanese and English through closer analyses of each evidential. Table 8 contains the percentages of frequencies of the different groups of evidentials, such as yoo da "it seems" and to kiita "I heard" in Japanese and English. The number of the total in this table is all productions drawn from twelve situations by $12 \mathrm{~J}$-speakers and $15 \mathrm{JF}$ learners. This section discusses outstanding result from the use of lexical evidentials and reported evidentials ${ }^{12}$.

12 Direct group was discussed in a previous section (see p.35). Other productions and ungrammatical evidentials will not be discussed in this study in order to focus on only the outstanding results. 
Table 8

Frequency of the Use of the Different Groups of Evidentials

\begin{tabular}{|c|c|c|c|c|c|}
\hline $\begin{array}{c}\text { Featur } \\
\mathrm{e}\end{array}$ & $\begin{array}{c}\text { Japanese } \\
\text { Evidentials }\end{array}$ & $\begin{array}{c}\text { Native } \\
\text { Japanese } \\
\text { speaker's } \\
\text { production } \\
\text { in } \\
\text { Japanese } \\
(\mathrm{JJ})\end{array}$ & $\begin{array}{c}\text { Native } \\
\text { English } \\
\text { speakers' } \\
\text { production } \\
\text { in Japanese } \\
(\mathrm{EJ})\end{array}$ & $\begin{array}{c}\text { Native } \\
\text { English } \\
\text { speakers' } \\
\text { production } \\
\text { in English } \\
\text { (EE) }\end{array}$ & $\begin{array}{c}\text { English } \\
\text { Evidentials }\end{array}$ \\
\hline \multirow{3}{*}{$\begin{array}{l}\text { Lexic } \\
\text { al } \\
\text { Evide } \\
\text { ntials }\end{array}$} & $\begin{array}{c}\text { Hearsay } \\
\text { soo da }\end{array}$ & $\begin{array}{c}6.3 \% \\
(9)\end{array}$ & $\begin{array}{c}27.2 \% \\
(49)\end{array}$ & \multirow{3}{*}{$\begin{array}{l}11.1 \% \\
(20)\end{array}$} & \multirow[t]{3}{*}{$\begin{array}{l}\text { apparently } \\
\text { it seems } \\
\text { it looks like }\end{array}$} \\
\hline & rashii & $\begin{array}{c}34.0 \% \\
(49)\end{array}$ & $\begin{array}{c}8.3 \% \\
(15)\end{array}$ & & \\
\hline & $\begin{array}{c}\text { yoo da } \\
\text { mitai da }\end{array}$ & $\begin{array}{c}16.7 \% \\
(24)\end{array}$ & $\begin{array}{c}1.7 \% \\
(3)\end{array}$ & & \\
\hline \multirow[t]{3}{*}{$\begin{array}{l}\text { Repor } \\
\text { ted } \\
\text { Evide } \\
\text { ntials }\end{array}$} & $\begin{array}{l}\text { Subject is the } \\
\text { speaker } \\
\text { to }(\text { tte }) \\
\text { kiitalyonda }\end{array}$ & $\begin{array}{c}2.8 \% \\
(4)\end{array}$ & $\begin{array}{c}6.7 \% \\
(12)\end{array}$ & $\begin{array}{c}19.4 \% \\
(35)\end{array}$ & $\begin{array}{l}\text { I heard } \\
\text { I read }\end{array}$ \\
\hline & $\begin{array}{l}\text { Subject is } \\
\text { other than } \\
\text { speaker } \\
\text { to itta/ to } \\
\text { kaiteatta }\end{array}$ & $\begin{array}{c}4.2 \% \\
(6)\end{array}$ & $\begin{array}{c}17.2 \% \\
(31)\end{array}$ & $\begin{array}{c}30.6 \% \\
(55)\end{array}$ & $\begin{array}{l}\text { he said } \\
\text { she said } \\
\text { it said }\end{array}$ \\
\hline & $\begin{array}{l}\text { Unclear } \\
\text { Source tte } \\
\text { N/A }\end{array}$ & $\begin{array}{l}13.9 \% \\
(20)\end{array}$ & $\begin{array}{l}2.8 \% \\
(5)\end{array}$ & N/A & $\begin{array}{c}\text { tte may not } \\
\text { have no English } \\
\text { linguistic } \\
\text { element }\end{array}$ \\
\hline \multicolumn{2}{|c|}{$\begin{array}{c}\text { Other Productions that } \\
\text { Do Not Belong to Any } \\
\text { Groups }\end{array}$} & $\begin{array}{c}6.3 \% \\
(9)\end{array}$ & $\begin{array}{c}6.7 \% \\
(12)\end{array}$ & $\begin{array}{l}5.0 \% \\
(9)\end{array}$ & $\begin{array}{c}\text { Other } \\
\text { Productions }\end{array}$ \\
\hline \multicolumn{2}{|c|}{$\begin{array}{c}\text { Direct } \\
\text { Statement }\end{array}$} & $\begin{array}{c}16.0 \% \\
(23)\end{array}$ & $\begin{array}{c}25.0 \% \\
(45)\end{array}$ & $\begin{array}{c}33.9 \% \\
(61)\end{array}$ & $\begin{array}{c}\text { Direct } \\
\text { Statement }\end{array}$ \\
\hline \multicolumn{2}{|c|}{ Ungrammatical } & $\begin{array}{c}0.0 \% \\
(0)\end{array}$ & $\begin{array}{c}4.4 \% \\
(8)\end{array}$ & $\begin{array}{c}0.0 \% \\
(0)\end{array}$ & Ungrammatical \\
\hline \multicolumn{2}{|r|}{ Total } & 144 & 180 & 180 & Total \\
\hline
\end{tabular}

\section{3. 2. Overuse of Soo $D a$ among Lexical Evidentials}

Among lexical evidentials, yoo da, mitai da, soo da, and rashii, JF learners used soo da the most frequently. When comparing the frequency of soo da in JJ and EJ 
$(\mathrm{JJ}=6.3 \%, \mathrm{EJ}=27.2 \%), \mathrm{JF}$ learners used soo $d a$ three times more than $\mathrm{J}$-speakers. That is, learners tend to choose soo da, even when J-speakers would not choose it.

Makino and Tsutsui (2014) explain differences between lexical evidentials, rashii, inference soo da, and yoo da as follows.

(1) Kyoo wa ame ga furu rashii.

(From what I heard,) it seems that it will be rain today. (Makino \& Tsutsui, 2014; p.552)

(2) Kyoo wa ame ga furi soo da.

It looks like it's going to rain at any moment. (Makino \& Tsutsui, 2014; p.552)

(3) Kono hen wa yoku ame ga furu yoo da.

(Judging from the abundance of trees and moss,) it appears that it rains a lot around here. (Makino \& Tsutsui, 2014; p.552)

Rashii "usually expresses the speaker's conjecture based on what the speaker heard or read...[but] not firsthand" (p.550). Stem + soo da "expresses conjecture about what is going to happen or the current status of someone or something" (p.550) and is used for information obtained "usually based on what the speaker sees or feels, it is merely his guess and the degree of certainty in his statement is fairly low" (p.550). Yoo da is used for information that is "usually based on what the speaker sees or saw. However, unlike $[$ stem +$]$ soo da, this expression involves the speaker's reasoning process based on firsthand, reliable information and his knowledge" (p.550). That is, the primary emphasized function of these evidentials as introduced in the textbook is to express 
conjecture and inference but additionally they function as a conveyance of hearsay information. This hearsay function is not emphasized in textbooks such as JSL or Genki.

From this discussion, it may indicate that it would take too much time to internalize the pragmatic knowledge and differences, especially these lexical evidentials, rashii, inference soo da, and yoo da, due to their primary function of expressing of speaker's conjecture. Hearsay soo da, on the other hand, expresses only hearsay information, which is used "when the speaker conveys information obtained from some information sources without altering it" (p.409).

Additionally, one possible factor regarding the JF learners' overuse of hearsay soo da might be the textbook envelopments. All the JF learners in this study are students at a university that use the textbook Japanese: The Spoken Language (JSL). JSL introduces soo da in Lesson 21 as a grammatical pattern to express hearsay information, while other lexical evidentials, mitai da, yoo da, soo da, and rashii are introduced in Lesson 24 as inferential evidentials. Among other lexical evidentials, hearsay soo da is one that does not contain the speaker's conjecture. However, since JSL presents soo da as hearsay and focuses on the conjecture aspect of other evidentials, on the other hand, JF learners might use soo da very frequently when presenting information from an aural source. While J-speaker chosen variety of evidentials, such as yoo da and mitai da.

\section{3. 3. Yoo Da and Mitai Da}

The third most common evidentials used by J-speakers is inference yoo da/ mitai $d a$. J-speakers used these evidentials much more frequently than JF learners' EJ 
$(\mathrm{JJ}=16.7 \%, \mathrm{EJ}=1.7 \%)$. According to JSL (1988) and McCready and Ogata (2007), yoo da and mitai $d a$ are used when the speaker conveys information made by inference, they are not pure hearsay. However, as the data shows, even when participants were merely asked to convey hearsay information to a third party, participants, especially J-speakers, used inference evidentials.

The follow-up questions could reveal possible reasons for J-speakers' use of yoo $d a$ and mitai $d a$. During the follow-up interview, when I asked the question "Does the use of evidentials differ when conveying the information immediately or one day after?" one of the J-speakers answered as follows:

(1) (Tugi no hi wa) jibun no kioku ga aimai ni naru kara jibun de hanashi wo tukuttesimau koto ga arunja nai kana. Nandattakke tte omoi nagara jibun de hanashi wo tukutte mitari.

(When converting the information one day after,) my memory becomes ambiguous so it might be the case that I made up my own story. While I'm thinking of what (the original information) was, I'm giving a story I made-up or something.

This answer suggests that J-speakers may use yoo da and mitai da in some situations, such as one day after, when the hearsay information became ambiguous in his/her mind. Additionally, another J-speaker answered the same question as follows: 

motteinai to tsutaenai desu ne... Shimpyo sei ga nai mono da to, jibun de chekku shite kara tsutaemasu.

When it comes to one day after, (I) do not convey that information unless I have confidence regarding the content of information. If it's not something credible, I will first check myself and then convey the information.

That is, when time passes, the degree of reliability becomes lower so s/he feels it is necessary to check the information him/herself. These J-speakers' answers indicate that even when participants were asked to convey the information, inference or conjecture processes occur when they imagine situations.

This suggests future studies should address the speaker's thought toward using yoo da and mitai da, focusing on what goes through the speaker's mind, whether they simply convey the information they heard, or actually internalize the information and make inferences before conveying the information or taking action.

While J-speakers used yoo da and mitai da often, JF learners did not use them much $(\mathrm{JJ}=16.7 \%, \mathrm{EJ}=1.7 \%)$. One possible factor explaining the very low frequency of $\mathrm{JF}$ learners' yoo da and mitai da in Japanese is the fact that their primary function is conjecture (McCready and Ogata, 2007) and it is difficult to internalize them, so learners may choose another expression and avoid using them. 


\section{3. 4. Tte}

Regarding the use of tte, J-speakers tend to use tte more frequently, about $11 \%$ more than learners $(\mathrm{JJ}=13.9 \%, \mathrm{EJ}=2.8 \%)$. The data also revealed that nine out of twelve $\mathrm{J}$-speakers used tte in some situations, while only three out of fifteen learners used tte; two from fourth-year, one from the graduate Japanese program ${ }^{13}$ and none of the learners from third-year.

One possible explanation for this difference in $\mathrm{JJ}$ and $\mathrm{EJ}$ is that tte may not have an English linguistic equivalent (Ishida, 2006, Mushin 2001), so learners may not fully understand the pragmatic rules for its usage or may ignore it. The relative frequency of tte, $13.9 \%$, by $\mathrm{J}$-speakers indicates that tte is commonly used in Japanese. McCready and Ogata (2007) stated that tte may play a very important role in terms of registering formal and informal situations, and as a result, it may affect the relationship between the speakers and interlocutors. According to them, tte is used within only causal contexts, such as talking to his/her family or friends.

In addition, Kamada (1990) also mentioned that textbook contexts may affect learners' Japanese language, that is, many textbooks, such as JSL, contain a lot of formal situations in the exercises with new grammar, such as "office," or "talking to superior like teachers or host family," and learners often practice Japanese language in these situations in the classroom, but not as much as in casual situations. As a result, JF learners may not have enough training with a wide variety of contexts involving various

\footnotetext{
13 Some JF learners above fourth-year Japanese and graduate student have been studying Japanese more than four years, so it might be difficult to generalize. However, the data of very low frequency tte by JF learners still supports that they tend not to not use tte in Japanese in hearsay situations compared to J-speakers.
} 
evidentials, especially expressions used in casual situations. This register and use of evidentials will be discussed in more detail in Table 9.

\section{3. 5. To Itta and Directness and Indirectness}

Comparing the evidential, to itta and "he/she said" in JJ and in EE, JF learners used this expression mostly in EE, while J-speakers used it less than 5\% in their L1 $(\mathrm{EE}=30.6 \%, \mathrm{JJ}=4.2 \%)$. This evidential, to itta "he/she said" shows that the speaker obtained the information explicitly from an outside source. Additionally, when comparing the reporting evidential to itta and other evidentials such as rashii, yoo da and mitai da, or to kiita and to yonda, to itta does not involve the speaker's action. That is, the speaker merely reports the fact that someone has expressed some information, and s/he does not take responsibility as to the certainty of the information. In this sense, sentences with to itta can be clear and objective compared to other evidentials and do not contain room for ambiguity.

This difference in use of tte itta may reflect cultural preferences of directness and indirectness, because English L1 speakers prefer directness, while Japanese prefer ambiguity (Trent, 1998). However, when comparing JJ, EJ, and EE (JJ=4.2\%, $\mathrm{EJ}=17.2 \%, \mathrm{EE}=30.6 \%$ ), the reported speech of tte itta or "s/he said" in EJ is much less frequent than EE, which leads us to assume that JF learners try to adjust Japanese evidentials. 


\section{4. 1. The Use of Evidentials Depending on the Addressee}

Table 9 shows the use of each type of evidential in JJ, EJ and EE depending on the addressee. The total number of $\mathrm{JJ}$ is 144 , produced from 12 situations by 12 participants. These 144 productions in JJ were divided into two groups, friends and superiors, in order to look for the differences in relation to evidentials and addressees, thus the subtotal of JJ's production became 72 for friends and 72 for superiors. Likewise for $\mathrm{EJ}$ and $\mathrm{EE}$, each of the total number of productions produced from 12 situations by 15 participants is 180 for friends and superiors. Since the total number of J-speakers and JF learners are different, the differences are shown in percentages.

According to Ishida (2006), as discussed in Chapter 3, comparing relationships between evidentials and addressees reveal the speaker's politeness strategy. Politeness strategy was proposed by Brown and Levinson (1978). Brown and Levinson propose a universal politeness theory. According to $\mathrm{B} \& \mathrm{~L}$, in social interactions, in order to maintain their good manners and relationships, people use strategies such as positive politeness, which appeal to the hearer through compliments or jokes and showing friendliness, and negative politeness, which protects the speaker by hedging and apologetic expressions that create social distance. Ohta (1991) insisted that Brown and Levinson's politeness strategies and face-threatening acts are very important in Japanese society. He also says that there is a wider range of actions to alleviate face-threatening acts and politeness strategies for Japanese compared with Americans. Integrating the notion of politeness strategies into the theory of the territory of information, Kamio (1997) proposed that J-speakers tend to use more evidentials to make his/her sentences softer, but this does not affect English speakers, since English has different politeness strategies. To see the 
differences in relation to evidentials and politeness strategy, Ishida (2006) created situations to convey the information to either the speaker's superior or friend. This section aims to find out which evidentials learners are aware of and which pragmatic rules are internalized. 
Table 9

Frequency of the Use of the Types of Evidentials Depending on the Addressee

\begin{tabular}{|c|c|c|c|c|c|c|c|}
\hline \multirow[b]{2}{*}{ Feature } & & \multicolumn{2}{|c|}{$\begin{array}{l}\text { Native Japanese } \\
\text { speaker's } \\
\text { production in } \\
\text { Japanese }(\mathrm{JJ})\end{array}$} & \multicolumn{2}{|c|}{$\begin{array}{l}\text { Native English } \\
\text { speakers' } \\
\text { production in } \\
\text { Japanese }(\mathrm{EJ})\end{array}$} & \multicolumn{2}{|c|}{$\begin{array}{l}\text { Native English } \\
\text { speakers' } \\
\text { production in } \\
\text { English (EE) }\end{array}$} \\
\hline & & Friend & $\begin{array}{c}\text { Superi } \\
\text { or }\end{array}$ & Friend & $\begin{array}{l}\text { Superi } \\
\text { or }\end{array}$ & Friend & $\begin{array}{l}\text { Superi } \\
\text { or }\end{array}$ \\
\hline \multirow{3}{*}{$\begin{array}{l}\text { Lexical } \\
\text { Evident } \\
\text { ials }\end{array}$} & $\begin{array}{c}\text { Hearsay } \\
\text { soo da }\end{array}$ & $\begin{array}{c}0.0 \% \\
(0)\end{array}$ & $\begin{array}{c}12.5 \% \\
(9)\end{array}$ & $\begin{array}{c}28.9 \% \\
(26)\end{array}$ & $\begin{array}{c}25.6 \% \\
(23)\end{array}$ & \multirow{3}{*}{$\begin{array}{c}13.3 \% \\
(12)\end{array}$} & \multirow{3}{*}{$\begin{array}{c}8.9 \% \\
(8)\end{array}$} \\
\hline & rashii & $\begin{array}{c}45.8 \% \\
(33)\end{array}$ & $\begin{array}{c}20.8 \% \\
(15)\end{array}$ & $\begin{array}{c}8.9 \% \\
(8)\end{array}$ & $\begin{array}{c}7.8 \% \\
(7)\end{array}$ & & \\
\hline & $\begin{array}{c}\text { inference yoo } \\
\text { dal mitai da }\end{array}$ & $\begin{array}{c}11.1 \% \\
(8)\end{array}$ & $\begin{array}{c}23.6 \% \\
(17)\end{array}$ & $\begin{array}{l}2.2 \% \\
(2)\end{array}$ & $\begin{array}{c}3.3 \% \\
(3)\end{array}$ & & \\
\hline \multirow[t]{3}{*}{$\begin{array}{l}\text { Reporte } \\
\text { d } \\
\text { Evident } \\
\text { ials }\end{array}$} & $\begin{array}{l}\text { Subject is the } \\
\text { speaker } \\
\text { to }(\text { tte }) \\
\text { kiita/yonda }\end{array}$ & $\begin{array}{l}0 \% \\
(0)\end{array}$ & $\begin{array}{c}4.2 \% \\
(3)\end{array}$ & $\begin{array}{c}3.3 \% \\
(3)\end{array}$ & $\begin{array}{c}10.0 \% \\
(9)\end{array}$ & $\begin{array}{c}12.2 \% \\
(11)\end{array}$ & $\begin{array}{c}25.6 \% \\
(23)\end{array}$ \\
\hline & $\begin{array}{l}\text { Subject is } \\
\text { other than } \\
\text { speaker } \\
\text { to itta/ to } \\
\text { kaiteatta }\end{array}$ & $\begin{array}{c}2.8 \% \\
(2)\end{array}$ & $\begin{array}{l}5.6 \% \\
(4)\end{array}$ & $\begin{array}{c}13.3 \% \\
(12)\end{array}$ & $\begin{array}{c}21.1 \% \\
(19)\end{array}$ & $\begin{array}{c}30.0 \% \\
(27)\end{array}$ & $\begin{array}{c}32.2 \% \\
(29)\end{array}$ \\
\hline & $\begin{array}{l}\text { Unclear } \\
\text { Source } \\
\text { tte }\end{array}$ & $\begin{array}{c}26.4 \% \\
(19)\end{array}$ & $\begin{array}{c}2.8 \% \\
(2)\end{array}$ & $\begin{array}{c}5.6 \% \\
(5)\end{array}$ & $\begin{array}{c}0.0 \% \\
(0)\end{array}$ & N/A & N/A \\
\hline \multicolumn{2}{|c|}{$\begin{array}{c}\text { Other Productions That } \\
\text { Do Not Belong to Any } \\
\text { Groups }\end{array}$} & $\begin{array}{c}2.8 \% \\
(2)\end{array}$ & $\begin{array}{c}9.7 \% \\
(7)\end{array}$ & $\begin{array}{c}5.6 \% \\
(5)\end{array}$ & $\begin{array}{c}7.8 \% \\
(7)\end{array}$ & $\begin{array}{c}4.4 \% \\
(4)\end{array}$ & $\begin{array}{c}6.7 \% \\
(5)\end{array}$ \\
\hline \multicolumn{2}{|c|}{$\begin{array}{c}\text { Direct } \\
\text { Statement }\end{array}$} & $\begin{array}{c}11.1 \% \\
(8)\end{array}$ & $\begin{array}{c}20.8 \% \\
(15)\end{array}$ & $\begin{array}{c}28.9 \% \\
(26)\end{array}$ & $\begin{array}{c}20.1 \% \\
(19)\end{array}$ & $\begin{array}{c}41.1 \% \\
(37)\end{array}$ & $\begin{array}{c}26.7 \% \\
(24)\end{array}$ \\
\hline \multicolumn{2}{|c|}{ Ungrammatical } & N/A & N/A & $\begin{array}{c}3.3 \% \\
(3)\end{array}$ & $\begin{array}{c}5.6 \% \\
(5)\end{array}$ & N/A & N/A \\
\hline \multicolumn{2}{|c|}{ Subtotal } & 72 & 72 & 90 & 90 & 90 & 90 \\
\hline \multicolumn{2}{|r|}{ Total } & \multicolumn{2}{|c|}{144} & \multicolumn{2}{|c|}{180} & \multicolumn{2}{|c|}{180} \\
\hline
\end{tabular}

The table shows some remarkable differences. Firstly, there are huge differences in the use of soo da and rashii by J-speakers and JF learners. As for soo da, J-speakers did not use soo da to friends at all, while learners used it frequently $(\mathrm{JJ}=0 \%, \mathrm{EJ}=26)$. Secondly, 
the use of tte also created a huge gap between J-speakers and JF learners. J-speakers used tte to friends much more often than JF learners' $(\mathrm{JJ}=26.4 \%, \mathrm{EJ}=5.6 \%)$

\section{4. 2. Hearsay Soo Da and Rashii}

Comparing hearsay soo da and rashii in $\mathrm{JJ}$ and EJ, the use of soo da and rashii are different in relation to the addressee. Soo $d a$ was used by J-speakers in very specific situations, that is, only to superiors, while rashii was used more often to friends who are of equal status. However, the data in EJ shows that learners used soo da more often to their friends $(\mathrm{JJ}=0 \%, \mathrm{EJ}=26.7 \%)$. This could suggest that $\mathrm{J}$-speakers do not use soo $d a$ when communicating with their friends, while JF speakers did.

During the follow-up questions, when J-speakers answered if the use of evidentials differs between friends and superior, some of them were also asked the question "do you use soo da or soo da yo to your friends, such as ame ga huru soo da "I heard that it will be rain today?" One answered Sore wa tyotto iimasen ne "I don't really say it", or Nanka henna kanji ga simasu "it sounds odd somehow", and Rashii yo tte yuu to omoimasu "I think I would rather say rashii." From J-speakers' answers elicited by follow-up questions, it can be said that some J-speakers are sensitive to social relationships and use of soo da, and they tend to not use soo da with friends. Additionally, according to Ishiguro (2011) and Sawanishi (2002), soo da may express the speaker is irresponsible. They argue that since soo $d a$ expresses pure hearsay and does not involve the speaker's action, namely inference, soo da may sound less committed. The speaker may want to show her friendliness and closeness, especially toward friends, more than she is concerned about accuracy and reliability of information; hence, J-speakers may 
more often choose evidentials such as mitai da or rashii, which express speakers' greater involvement.

It should be noted that, considering soo da and its use, textbooks, such as JSL and A Dictionary of Basic Japanese Grammar (Jorden and Noda, 1987; Makino, \& Tsutsui, 2014), do not give any explanations in terms of formal and informal register for soo da. However, from this quantitative study and follow-up questions, this study revealed that J-speakers use evidentials such as rashii and tte rather than soo da to friends. This suggests that when teaching soo da in the classroom, instructors should inform students of this pragmatic knowledge of formal and informal registers to supplement textbook explanations.

\section{4. 3. Tte and Its Pragmatic Knowledge}

As Table 9 shows, when comparing differences in relation to addressees, J-speakers used tte to friends more often than to superiors in Japanese (friend $=26.4 \%$, superior $=2.8 \%$ ), as well as JF learners (friend $=5.6 \%$, superior $=0.0 \%$ ). This indicates that although learners' use of tte was much less frequent than J-speakers, JF learners who used tte seem to have incorporated the pragmatic rules of tte, that is, tte is generally not used to a superior.

In the data, there are two productions containing tte which are interesting since they combine distal style + tte,. For example, Abe soori ga jiko ni atta $n$ desu tte "the prime minister Abe got an accident" and Miki ga sukoshi yoku natte, taiin shita n desu tte "Miki got a little better and came out of the hospital." This sentence shows a certain 
degree of politeness even though it contains tte, since the proposition "jiko ni atta" ends with desu.

The data regarding soo da and tte indicates that learners would benefit in instruction that they should use tte rather than soo da when communicating with friends.

\section{5. Pedagogical Implications}

This section addresses pedagogical implications regarding evidentials soo da and tte used by JF learners. First, this study revealed that JF learners tend to choose soo da more than other lexical evidentials such as rashii, mitai da and yoo da while J-speakers use a variety of evidentials. By choosing evidentials appropriately, the speaker can show his/her stance more clearly, such as how the speaker obtained the information and whether or not the second-hand information is conveyed as the speaker's inference, as well as register or formality. The primary pedagogical implication is that instructors should provide opportunities to practice within a variety of contexts, in order to show the differences in functions between pure hearsay, inference, or conjecture. For example, instructors could provide contexts that contain only pure hearsay information and contexts in which the speaker makes inference. Compare the following two contexts:

(1) Your friend said, "Kono mise no sushi oishii yo".

"This restaurant's sushi is good."

(2) Your friend said, "Kono mise ni moo sankai itta yo".

"I have been this restaurant three times." 
For the former situation learners are expected to convey the information by saying Kono mise no sushi oisii soo desu "(I heard that) this restaurant's sushi is good," and for the latter, one conveys Kono mise no sushi oisii mitai desu "It seems that this restaurant's sushi is good" with the speaker's inference. By doing these kinds of exercises, learners become able to make choices among pure hearsay markers or other evidentials that indicate the speaker's inference.

Additionally, by analyzing evidentials and their relation to the addressee, this study revealed that while JF learners used soo da to friends frequently, J-speakers did not use soo da when communicating with friends but used other evidentials such as rashii or tte to express hearsay information. The instructor should mention that soo da is not commonly used to friends and encourage them to use other evidentials such as rashii or tte.

This study also revealed that the JF learners tend not to use tte compared to J-speakers. Tte is used usually between interlocutors who are in the same status in casual contexts, but it seems that there is no exact equivalent in English. Again, instructors should provide both formal and informal contexts and encourage learners using tte by showing register differences. For example, instructors can first introduce the context to convey hearsay evidentials to a superior and have learners practice to use evidentials soo desu or mitai desu at first, then change the interlocutor to a friend and practice tte. Also, when introducing tte, instructors can explain how tte is more commonly used by J-speakers than tte itte ita "s/he said"or tte yonda "I read" in casual contexts. With these instructions, learners may be able to pay more attention to J-speakers' productions in 
terms of their use of evidentials in order to internalize pragmatic rules both in and outside of the classroom. 


\section{CHAPTER 5:}

\section{CONCLUSION}

This study found that English L1 learners of Japanese used evidentials less frequently both in English and Japanese compared with Japanese L1 speakers, which was the same as Ishida's findings. This difference in the learners' use of evidentials indicates that they may lack a full understanding of the pragmatic rules for Japanese evidentials and transfer L1 knowledge to Japanese, producing utterances that omit evidentials all together or use different evidentials from Japanese L1 speakers.

Additionally, by closely analyzing each type of evidential, such as soo da "I heard" or rashii "it seems," this study found other factors that may affect the speaker's choice of evidentials, such as cultural preferences, and learning environment. The close analysis of the evidentials also revealed some evidentials, such as rashii, yoo da, mitai da, $t t e$, that are difficult to internalize and require more experience for learners.

This study also suggested that Kamio's theory of territory of information and Ishida's study need to be modified. For Kamio's theory, in addition to discussing how the speaker's expertise, such as geographic familiarity, determines the form of sentences, other aspects of the speaker's background, such as their professions and personal interests and involvement with certain topics used in situations, should also be included. For Ishida's study, the factor of reliability of information needs to be reconsidered and explained in more detail, such as the type of media sources and how dense the conveyed information is. Also, Ishida's factor of addressees needs to be reconsidered regarding how and to what degree participants are concerned with politeness strategies in their daily lives. In order to find differences between Japanese and English pragmatic rules, English 
productions should be gathered from the English L1 speakers who have not studied other languages.

In conclusion, as discussed in the introduction and literature reviews, evidentials play a very important role in relation to sociolinguistics. Learners of Japanese need to be aware of Japanese pragmatic rules and use them in a variety of contexts. Using inappropriate evidentials, the speaker may convey the wrong impression about his/her stance toward the information or interlocutors and, as a result, this causes misunderstandings, or can give a negative impression. The findings in this study regarding new factors and learners' weaknesses would help advance our understanding about Japanese evidentials and help develop pedagogical approaches to the teaching of evidentials for learners of Japanese.

This study is an attempt at replicating Ishida's study regarding the investigation of evidentials in Japanese and English in order to provide data for future study and suggest for Japanese language pedagogy. This study used a small group of learners of Japanese at third-year, fourth-year, and graduate levels at a university in the United States. The total number of participants is small, with 15 learners of Japanese whose L1 is English, and 12 Japanese L1 speakers. Other groups of learners of Japanese may bear different results in their pragmatic ability to produce evidentials. Their learning background and where they grew up may also affect the use of evidentials. Therefore, the results of this study may not be generalizable.

The findings in this study suggest some revisions for future studies. As discussed in Chapter 4, the source of information and its reliability need to be reconsidered. In order to analyze the relationship between reliability and the use of evidentials, the 
situations should be designed to highlight differences between pragmatic rules in Japanese and English, such as addressees, place, formality with the topic, sources of information and so on. This study also suggests that the background of participants, such as their learning backgrounds or professions, should be considered more carefully. The sentence forms and use of evidentials change depending on participants' situations, such as their professions, interests, or relationships to the information of the context. Additionally, in order to make data as generalizable as possible, a study should include participants from multiple institutions, since learning environments, such as teaching approach and textbooks, may affect ability of use of target language to a great degree.

Moreover, it is found that the follow up interviews were important. Tapping into participants' inner thoughts may be helpful to account for patterns of evidential use. Further research in this direction will shed more light on the dynamic nature of development of pragmatic knowledge and pragmatic transfer regarding the use of evidentials. 


\section{REFERENCES}

Aoki, H. (1986). Evidentials in Japanese. In Chafe, W., \& Nichols, J. (Eds.), Evidentiality: The linguistic coding of epistemology. (pp. 223-239). Norwood: Ablex Publishing Corporation.

Banno, E., Ikeda, Y., Ohno, Y., \& Tokashiki K. (2011). Genki I: An integrated course in elementary Japanese (2nd ed.). Tokyo: Japan Times/Tsai Fong Books.

Brown, P., \& Levinson, C. (1987). Politeness: Some universals in language usage (Vol. 4). Cambridge: Cambridge University Press.

Chafe, W. (1986). Evidentials in Japanese. In Chafe, W., \& Nichols, J. (Eds.), Evidentiality: The linguistic coding of epistemology. (pp. 261-272). Norwood: Ablex Publishing Corporation.

Chafe, W., \& Nichols, J. (1986). Evidentiality: The linguistic coding of epistemology. Norwood: Ablex Publishing Corporation.

Christensen, M., \& Warnick, P. (2006). Performed culture: An approach to East Asian language pedagogy. (Vol. 11). Columbus: Ohio State University.

Ellis, R. (1997). SLA Research and Language Teaching. Oxford: Oxford UP. Hasegawa, Y. (2015). Modality and evidentiality. In Japanese: A linguistic introduction (pp. 307-318). Cambridge: Cambridge University Press.

Ishida, K. (2006). How can you be so certain?: The use of hearsay evidentials by English speaking learners of Japanese. Journal of Pragmatics: An Interdisciplinary Journal of Language Studies, 38(8), 1281-1304. 
Ishiguro, K. (2011). Hanashi kotoba to kaki kotoba: Syonenji kyōiku no kiso siryō to shite, Hitotsubashi Daigaku Kenkyūshitsu, Gengo Bunka, 48, 15-35. https://doi.org/info:doi/10.15057/22843

Jorden, H., \& Noda, M. (1987). Japanese: The spoken language, part 1. New Haven: Yale University Press.

Jorden, H., \& Noda, M. (1988). Japanese: The spoken language, part 2. New Haven: Yale University Press.

Kamada, O. (1990). Reporting messages in Japanese as a second language. In Kamada, O., Jacobsen, W. (Eds.), On Japanese and how to teach it. (pp. 224-245). Tokyo: The Japan Times.

Kamio, A. (1994). The theory of territory of information: The case of Japanese. Journal of Pragmatics, 21(1), 67-100. https://doi.org/10.1016/0378-2166(94)90047-7

Kamio, A. (1995). Territory of information in English and Japanese and psychological utterances. Journal of Pragmatics, 24(3), 235-264. https://doi.org/10.1016/0378-2166(94)00064-L

Kamio, A. (1997). Territory of information. Amsterdam/Philadelphia: Benjamins Publishing.

Kamio, A. (2002). Zoku ‘jōhō no nawabari riron. Tokyo: Taisyūkan.

Kamio, A., \& Takami, K. (1998). Danwa to jōhō kozōu. Tokyo: Kenkyūsya Shuppan.

Kasper, Gabriele. (2008). Data collection in pragmatics research. In S. Helen (Ed.), Culturally speaking: Culture, communication and politeness theory (pp. 279303). London: Continuum. 
Lü, T., Ke, H., \& Zheng, D. (2011). Revisiting the theory of territory of information: How first-year university Chinese students handled first-hand and second-hand information. Journal of Pragmatics, 43(15), 3720-3744. https://doi.org/10.1016/j.pragma.2011.09.005

Makino, S., Kamada, O., \& Jacobsen, W. (1990). On Japanese and how to teach it: In honor of Seiichi Makino (1st ed.). Tokyo: Japan Times.

Makino, S., \& Tsutsui, M. (2014). A dictionary of basic Japanese grammar (1st. ed.). Tokyo: Japan Times.

McCready, E., \& Ogata, N. (2007). Evidentiality, modality and probability. Linguistics \& philosophy, 30(2), 147-206. https://doi.org/10.1007/s10988-007-9017-7

Mushin, I. (1998). Evidentiality and epistemological stance in Macedonian, English and Japanese narrative. (Doctoral dissertation) Retrieved from Dissertation Abstracts International, Section A: The Humanities and Social Sciences.

Mushin, I. (2001). Japanese reportive evidentiality and the pragmatics of retelling. Journal of Pragmatics, 33(9), 1361-1390. https://doi.org/10.1016/S0378-2166(00)00078-3

Ohta, A. S. (1991). Evidentiality and politeness in Japanese. Issues in Applied Linguistics, 2(2), 211-238.

Okabe, R. (1983). Cultural assumption of east and west: Japan and the U.S. In W.B. Gudykunst (Ed.), In Intercultural communication theory: Current perspectives (pp. 21-44). Beverly Hills: Sage Publications. 
Sawanishi, T. (2002). Denbun ni okeru handan sei oyobi sono tokusei: $\ulcorner$ Soo da $\lrcorner\ulcorner$ rashii $\lrcorner$ $\ulcorner$ tono kotoda $\lrcorner \quad\ulcorner$ kiku $\lrcorner$ no danwa hyōgen wo tyūshin ni. Nihongo Nihonbunka, 28, 29-49. https://doi.org/info:doi/10.18910/11363

Trent, N. (1998). Cross-cultural discourse pragmatics speaking about hearsay in English and Japanese, Texas Papers in Foreign Language Education, 3(2), 1-31. 


\section{Appendix A:}

\section{INFORMED CONSENT FORM}

Title: Questionnaires regarding the use of hearsay expressions in Japanese and English

You are invited to participate in a research study conducted by Tomomi Matsumura from Portland State University, the department of World Languages and Literature. This research aims to compare the use of hearsay expressions in English and Japanese produced by Japanese learners and native Japanese speakers. In particular, the researcher hopes that through this comparison, it will be able to identify some tendencies in the use of hearsay expression in Japanese and English and errors frequently made by Japanese learners. This study is being conducted in partial fulfillment of the requirements for a masters' degree, under the supervision of Dr. Suwako Watanabe of Department of World Languages and Literatures at Portland State University. You were selected as a potential participant in this research because you are native speaker of either Japanese or English.

If you participate in this research, in the first part, you will be asked to produce utterances according to the situational descriptions the researcher provides. In the second part, you will be asked to answer questionnaire about the use of hearsay expression. If you are a learner of Japanese, you will be asked to produce utterances both in Japanese and English. If you are a native Japanese speaker, you will be asked to do so only in Japanese. During the first part, you will be recorded from the moment when the researcher starts reading a description until the participant produces twelve utterances regarding twelve descriptions using an audio recorder OLYMPUS Digital Voice Recorder WS-100. After taking a few minutes break, the researcher starts recording from the moment when the researcher asks the first questioner until you finish answering the last one, using the same voice recorder. The estimated length of time for the descriptions and questionnaires is from 20 minutes to 30 minutes. The risk to this study's participants is the participant's speech audio-recorded can be uncomfortable. Some people may be concerned that they may make mistakes. There is no right or wrong answer, you can take as long as time as you want to respond. It is important that you take part in the interview as naturally as possible.

Any information that is obtained in connection with this study and that can be linked to you or identify you will be kept confidential. The information you give me will be kept confidential to the extent permitted by law. Copies of the recordings, the transcriptions, and the consent forms will be kept in a secure locker in my house or in secure folders on the researcher's personal computer. When she report the findings of the study, she will use pseudonyms for any personal names. Your participation is voluntary. You do not have to take part in 
this study, and it will not affect your course grade or your relationship with Portland State University or her. You may also withdraw from this study at any time without affecting your course grade or relationship with Portland State University or her.

If you have questions or concerns about your participation in this study, contact Tomomi Matsumura, e-mail mtomomi@ pdx.edu or visit her office at Neuberger Hall M237B. If you have concerns about your rights as a research subject, please contact The PSU Office of Research Integrity, 1600 SW 4th Ave., Market Center Building, Ste. 620, Portland, OR 97201; phone (503) 725-2227 or 1 (877) 480-4400; email hsrrc@pdx.edu.

Your signature indicates that you have read and understand the above information and agree to take part in this study. The researcher should provide you with a copy of this form for your own records.

Printed Name

Signature 


\section{Appendix B:}

\section{E-MAIL TO JAPANESE LEARNERS}

Title: "Seeking Participants for a Research Study"

Dear [class name] students,

Tomomi Matsumura is looking for participants for her research study. You are receiving this email because you are a student at Portland State University who learns Japanese language.

This study is about the use of hearsay expressions in Japanese and English, such as "she says," "it seems" in English and tte, soo da in Japanese. If you are a Japanese learner and agree to take part in this study, you would be asked to convey to a third person the information based on twelve situations Tomomi reads in Japanese and English. You would be also asked your notions about differences between Japanese and English in terms of the use of hearsay expressions. However, if you are interested in participating, please don't prepare anything ahead of time. The purpose of this research is to investigate reasons why Japanese hearsay expressions are difficult for native speakers to master.

To be able to take part in this study, individuals must be either a native English speaker and above 300-level in Japanese at PSU. It is determined to investigate a transfer effect from English to Japanese.

If you are interested in participating or have any questions about the study, please e-mail Tomomi Matsumura, mtomomi@pdx.edu or call [insert name and telephone number of contact]. For detailed information, please see attached consent form.

Portland State University allows researchers use email to send its faculty, staff, and student information about research opportunities as part of its research mission. Use of these email addresses has been approved by Human Subject Research Review Committee. The content of this email message has been approved by Portland State University- IRB Administrator, Office of Research Integrity. IRBs are charged with protecting the rights and welfare of people who take part in research studies.

Thank you for your consideration.

Tomomi Matsumura

Portland State University

Japanese Graduate Assistant 


\section{Appendix C:}

\section{E-MAIL TO NATIVE JAPANESE SPEAKERS}

Title: 日本語と英語の伝聞表現の使用の違いについて

日本人留学生の方へ

初めまして、ポートランド州立大学で日本語言語学を学んでいる松村朋美 と申します。現在、大学院で、日本語と英語の伝聞表現（と言っていた、 そうです、など）の使用違いについて研究しています。この研究は、日本 語学部の Dr. Suwako Watanabe の監督の下で、私の修士論文として行われ ています。

この主な目的には、アメリカ人英語話者と日本人日本語話者の伝聞表現を 比較することにより、それぞれの言語にどのような傾向が見られるかを考 察するというものです。また、アメリカ人日本語学習者と日本人日本語話 者の伝聞表現を含む発話を比較することで、アメリカ人学習者にとって難 しい表現を理解し、今後そのような表現をどのように指導していくのかを 研究します。

参加していただいた方のリサーチ結果は研究者の修士論文のための研究デ 一タとして使用されることになります。今回このリサーチにご参加頂く参 加者の方は、日本語母語話者としての被験者という立場になります。

内容 :

第三者から聞いた情報を、皆さんがどのように他者に伝えるのか、松村が 12 のシチュエーションを読み上げますので、そのシチュエーションを想像 していただいて、日本語で答えていただきます。その後、みなさんの伝聞 表現についての考えを聞く質問をしますので、その質問に答えていただき ます。このインタビューに関して、準備などは必要ありません。

日時：

みなさんのご都合が合う日時を伺います。インタビューは 15 分から 20 分 程度です。インタビューは、皆様のプライバシーを守るため、PSU 図書館 の個室を予約して行います。 
詳しい情報は、添付している同意書 (Informed Consent Form)をお読みくだ さい。この研究に関してご質問等がございましたら、お手数ですがこちら までご連絡お願い致します。 mtomomi@pdx.edu 


\section{Appendix D:}

\section{D2L ANNOUNCEMENT}

Title: "Seeking participants for a research study"

Dear [class name] students,

Tomomi Matsumura is looking for participants for her research study. This study is about the use of hearsay expressions in Japanese and English, such as "she says" or "it seems" in English and tte or soo da in Japanese.

What you do:

If you agree to take part in this study, you would be asked to convey the information to a third party based on twelve situations Matsumura reads in Japanese and English. You would be also asked about your thoughts about differences between Japanese and English in terms of the use of hearsay expressions. If you are interested in participating, please don't prepare anything ahead of time. The purpose of this research is to investigate reasons why Japanese hearsay expressions are difficult for native speakers to master.

Time and Location:

Matsumura would ask you the day when you are available, and provide a private room for your study. It would be conducted during winter term and take about 20-30 minutes in total.

For more detailed information, please read the e-mail and attached consent form you have received from Matsumura. Please remember this research does not affect any of your academic grades or relationship with your instructors or Matsumura.

If you are interested in participating or have any questions about the study, please email Tomomi Matsumura, mtomomi@pdx.edu. 


\section{Appendix E:}

\section{SITUATIONS}

12 English situations have been adopted from Ishida (2006: 1300-1304)

\section{Situation 1}

> You are studying abroad.

> When you were checking your e-mail at school, you find a message from your

$>$ father about your dog, Ben, which had been missing for a while.

$>$ "Ben came back yesterday."

$>$ A friend who was sitting right next to you asks about Ben.

$>$ "Did they find him?"

$>$ What would you say to him?

あなたは留学しています。

学校でメールをチェックしているとき、お父さんから

先日から失踪していた飼っている犬、ベンについて、

「ベンが戻ってきた」とメールが来ました。

その時、隣に座っている友達が、「ベン見つかった?」と聞いてきました。 友達に何と言いますか?

\section{Situation 2}

$>$ You are studying abroad in Japan.

$>$ You were checking your e-mail at home at night and find a message from your mother.

> Part of it says: "I saw President Clinton at a symphony concert yesterday."

$>$ Next day, you go to school and see your friend Greg and tell him about your mother.

$>$ How would you tell him?

Symphony concert: シンフォニーのコンサート

President: だいとうりょう 
あなたは留学しています。

夜、家でメールをチェックしているとき、お母さんからのメールを見つけました。 メールの一部にはこう書いてありました。

「昨日、安部総理を音楽会で見た」

次の日、学校に行って、あなたの友達の太郎にメールのことを伝えます。 ぞう伝えますか?

\section{Situation 3}

$>$ You are working in a company away from home.

$>$ Your mother calls you suddenly at your office and says:

$>$ "There was a huge earthquake here right now and our house is about to fall down."

$>$ Your boss comes to you after you hung up and says:

$>$ "Are you OK? You don't look good."

$>$ You tell your boss about what you just heard on the phone.

$>$ How would you tell him?

あなたは家から離れた会社で働いています。

お母さんから会社に電話があり、こう言われました。

「さっき大きい地震があって、家が崩壊しそうだった」

お母さんからの電話を切ったすぐ後に、上司が来てこう言いました。

「大丈夫? 顔色が良くないけじ‥」

上司に電話で話した内容を伝えます。

どう伝えますか?

\section{Situation 4}

> You are living by yourself away from home.

$>$ Your sister, Emma, who is with your family has been sick and in the hospital for a while.

$>$ One day, your mother calls you and says:

> "Emma's got a lot better and she came out from the hospital today."

$>$ Next day, your teacher who was concerned about your sister asks you: 
> "How's Emma doing?"

$>$ What would you tell him?

Came out from the hospital: たんいんする

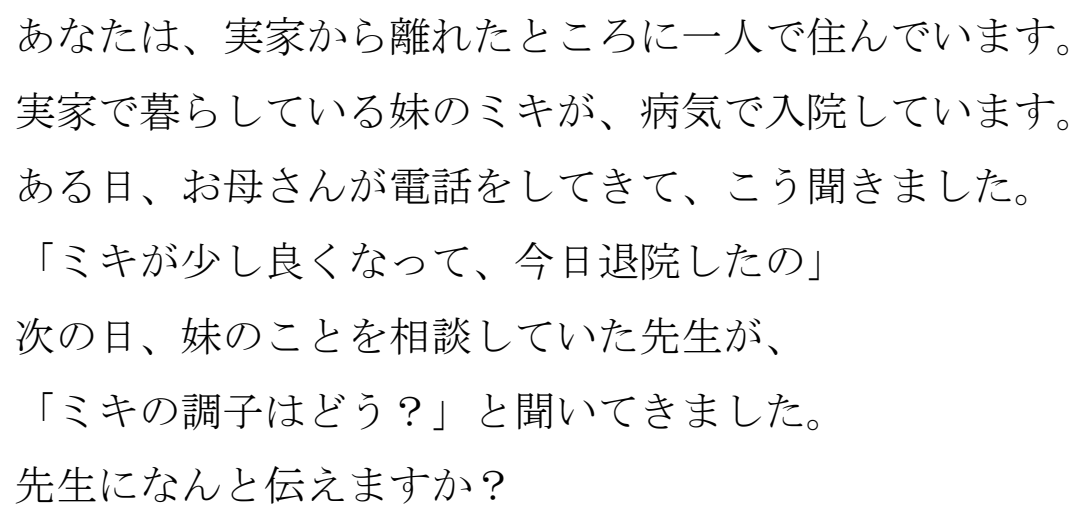

\section{Situation 5}

$>$ You are studying with your friend, Chris, at your home.

$>$ When you were studying, you get a call from Jenny who was supposed to join you two.

> She says: "I think I've got the flu, so I won't be able to make it over. Sorry.",

$>$ After you hang up with Jenny, how would you tell Chris about what you just heard?

あなたは友達のユウキとあなたの家で勉強しています。

勉強しているとき、後で合流して一緒に勉強するはずだったサトシから電話があ って

「熱があるから今日はいけない。ごめんね」と言いました。

電話を切った後、友達のユウキになんと言いますか?

\section{Situation 6}

$>$ You are talking with your friend, Richard, on the phone at home at night.

$>$ And Richard says: "I won a free trip to Japan today!"

$>$ Next day, you go to school and see Ben who is also a friend of yours.

$>$ You tell Ben about Richard's winning a trip to Japan.

$>$ How would you tell him? 
Won a trip: りょこうにあたる

あなたは友達のサクラと夜に電話で話しています。

サクラが次のことを言いました。

「今日、無料にヨーロッパ旅行に当選したの!」

次の日、学校に行って、サクラとあなたの共通の友達に、

サクラのヨーロッパ旅行の話を伝えます。

じう伝えますか?

\section{Situation 7}

> You see a friend at school and hear from him the following:

$>$ "I just saw on the news that Clinton was in an accident and is in critical condition right now."

$>$ Right after that you see a teacher whom you know very well and tell him about Clinton.

$>$ How would you tell that teacher?

In critical condition: じゅうだいだ

学校で友達からこう聞きました。

「阿部総理が交通事故にあって今重体なんだって」

その後すぐ、よく知っている先生に会って安部総理のことを伝えます。

先生にどうやって伝えますか?

\section{Situation 8}

$>$ Jenny is a classmate.

$>$ You get a call from her at night and she says:

$>$ 'I'm not feeling well and I think I'm going to skip class tomorrow. Can you tell the

$>$ teacher that I'll be absent?',

$>$ Next day, before class starts, you go to the teacher and tell her about Jenny.

$>$ How would you tell her?

ミカはクラスメイトです。 
ミカから、夜電話がありこう聞きました。

「気分が良くないから、明日のクラス休もうと思ってるの。先生に言っといてく れない?」

次の日、クラスが始まる前に、ミカのことを伝えます。

なんと言いますか?

\section{Situation 9}

> You are browsing the Internet at school.

$>$ Your friend is sitting right next to you.

$>$ You find the following news on the Internet.

$>$ "Michael Jackson has been kidnapped!"

$>$ How would you tell that news to your friend?

Browsing the Internet: インターネットをみている

Be kidnapped: ゆうかいされる

学校でインターネットをしています。

友達が隣に座っています。

インターネットで、つぎの記事を見つけました。

「仲居まさひろが誘拐された」

友達に何と言いますか?

\section{Situation 10}

> You are browsing the Internet at home before going to bed and you find the following:

$>$ "Mariah Carey will quit singing from next year."

$>$ Next day, you go to school as usual.

$>$ You see your friend and tell her about the news.

$>$ How would you tell her.

寝る前に、インターネットをしています。

次のニュースを見つけました。

「西野カナが歌手を引退する」 
次の日、いつもどおり学校に行きました。

友達に昨日のニュースを伝えます。

何といいますか?

\section{Situation 11}

> You are in a computer class and learning about how to use the Internet.

$>$ Today's assignment is to find an interesting piece of news and report it to the teacher.

$>$ You find the following news:

$>$ "Gorbachev is going to show up in a commercial for Pizza Hut."

$>$ You report this news to the teacher right away.

$>$ How would you report?

Show up in a commercial: コマーシャルにでる

コンピューターのクラスの時間で、インターネットの使い方を勉強しています。 今日はクラスで、インターネットでニュースを見つけて先生にレポートします。 あなたは、こんなニュースを見つけました。

「小泉元総理がピザハットのコマーシャルに出る」

すぐに、先生にレポートします。

なんと言いますか?

\section{Situation 12}

$>$ You were listening to the radio at home at night and you hear about today's women's volleyball game:

$>$ "UH beat BYU",

$>$ Next day you go to school and the teacher asks you whether you know the results.

$>$ How would you tell him?

夜、家で、今日の野球のニュースをラジオで聞いています。

「阪神が巨人に勝ちました。」

次の日、学校に行くと、先生がゲームの結果を聞いてきました。 先生になんと言いますか? 


\section{Appendix F:}

\section{FOLOW-UP QUESTIONS}

"Please answers these questions"

Question 1: Does the use of hearsay expressions differ depending on source of information friends or media such as internet and TV? If so, how and why? ("The source of information")

Question 2: Does the use of hearsay expressions differ depending on to whom you convey information whether to friends or superiors? If so, how and why? ("Recipients")

Question 3: Does the use of hearsay expressions differ depending on when you convey information whether immediate or one day after? If so, how and why? ("The timing of conveyance")

Question 4: Does the use of hearsay expressions differ between Japanese and English? If so, why and how?

mple of Japanese hearsay: soo, rashii, and yoo da, to itta, kiita, yonda, tte...

Examples of English hearsay: it seems like, it says, she said, according to... 